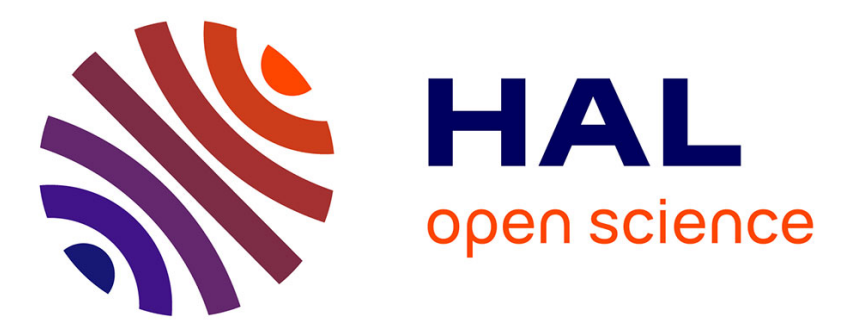

\title{
Insights into the borohydride electrooxidation reaction on metallic nickel from operando FTIRS, on-line DEMS and DFT
}

\author{
A. G. Oshchepkov, G. Braesch, G. Rostamikia, A. Bonnefont, M. J. Janik, \\ Marian Chatenet, E. R. Savinova
}

\section{To cite this version:}

A. G. Oshchepkov, G. Braesch, G. Rostamikia, A. Bonnefont, M. J. Janik, et al.. Insights into the borohydride electrooxidation reaction on metallic nickel from operando FTIRS, on-line DEMS and DFT. Electrochimica Acta, 2021, 389, pp.138721. 10.1016/j.electacta.2021.138721 • hal-03504844

HAL Id: hal-03504844

https://hal.univ-grenoble-alpes.fr/hal-03504844

Submitted on 29 Dec 2021

HAL is a multi-disciplinary open access archive for the deposit and dissemination of scientific research documents, whether they are published or not. The documents may come from teaching and research institutions in France or abroad, or from public or private research centers.
L'archive ouverte pluridisciplinaire HAL, est destinée au dépôt et à la diffusion de documents scientifiques de niveau recherche, publiés ou non, émanant des établissements d'enseignement et de recherche français ou étrangers, des laboratoires publics ou privés. 


\title{
Insights into the Borohydride Electrooxidation Reaction on Metallic Nickel from operando FTIRS, on-line DEMS and DFT
}

\author{
A. G. Oshchepkov ${ }^{1,2 *}$, G. Braesch ${ }^{3}$, G. Rostamikia ${ }^{4}$, A. Bonnefont ${ }^{5}$, M. J. Janik ${ }^{4}$, M. \\ Chatenet $^{3}$ and E. R. Savinova ${ }^{1 *}$ \\ ${ }^{1}$ Institut de Chimie et Procédés pour l'Energie, l'Environnement et la Santé, UMR 7515 CNRS- \\ University of Strasbourg, 67087 Strasbourg Cedex, France \\ ${ }^{2}$ Boreskov Institute of Catalysis, 630090 Novosibirsk, Russia \\ ${ }^{3}$ Univ. Grenoble Alpes, Univ. Savoie Mont Blanc, CNRS, Grenoble INP*, LEPMI, 38000 \\ Grenoble, France \\ *Institute of Engineering and Management Univ. Grenoble Alpes \\ ${ }^{4}$ Department of Chemical Engineering, Pennsylvania State University, University Park, PA, \\ 16802, USA \\ ${ }^{5}$ Institut de Chimie et Procédés pour l'Energie, l'Environnement et la Santé, UMR 7515 CNRS- \\ University of Strasbourg, 67087 Strasbourg Cedex, France
}

\begin{abstract}
Direct Borohydride Fuel Cells (DBFCs) are considered as promising power sources for portable and mobile applications. Their advantages are high theoretical energy density, and high theoretical cell voltage. Metallic Ni has recently emerged as a promising electrode material for DBFCs. In this work we combine electrochemical, operando Fourier-Transform infrared spectroscopy (FTIRS), and online differential electrochemical mass spectrometry (DEMS) measurements with density functional theory (DFT) calculations to advance the understanding of the borohydride oxidation reaction on $\mathrm{Ni}$.

Keywords

Borohydride oxidation reaction; polycrystalline nickel electrode; Fourier Transform Infrared Spectroscopy; Differential Electrochemical Mass Spectrometry; Density Functional Theory calculations.
\end{abstract}

\footnotetext{
${ }^{*}$ Corresponding authors:

oshchepkov@catalysis.ru

Elena.Savinova@unistra.fr
} 


\section{Introduction}

Thanks to its high energy density, non-toxicity, facile storage and transportation, sodium borohydride $\left(\mathrm{NaBH}_{4}\right)$ is considered as a promising carbon-free energy carrier. Direct Borohydride Fuel Cells (DBFCs), which utilize $\mathrm{NaBH}_{4}$ as a fuel, are considered as promising power sources for portable and mobile applications due to their high theoretical cell voltage, high theoretical number of transferred electrons (8) and the ensuing high theoretical energy density. However, currently available platinum group metal $(\mathrm{Pt}, \mathrm{Pd})$-based electrocatalysts do not allow one to take full advantage of the low standard potential of the borohydride oxidation reaction (BOR, Eq1 and $\mathrm{Eq} 1^{*}$ ) due to the hydrogen evolution reaction competing with the BOR at potentials below $0 \mathrm{~V} v s$ RHE (HER, Eq2) and heterogeneous hydrolysis of $\mathrm{BH}_{4}^{-}(\mathrm{Eq} 3)$ as well catalyzed by transition metals [1].

$$
\begin{aligned}
& \mathrm{BH}_{4}^{-}+8 \mathrm{OH}^{-} \rightleftarrows \mathrm{BO}_{2}^{-}+6 \mathrm{H}_{2} \mathrm{O}+8 \mathrm{e}^{-} \quad E^{0}=-0.41 \mathrm{~V} \text { vs } \mathrm{RHE} \quad \text { (Eq1) or } \\
& \mathrm{BH}_{4}^{-}+8 \mathrm{OH}^{-} \rightleftarrows \mathrm{B}(\mathrm{OH})_{4}^{-}+4 \mathrm{H}_{2} \mathrm{O}+8 \mathrm{e}^{-} \quad(\mathrm{Eq} 1 *) \\
& 2 \mathrm{H}_{2} \mathrm{O}+2 \mathrm{e}^{-} \rightleftarrows 2 \mathrm{OH}^{-}+\mathrm{H}_{2} \quad E^{0}=0 \mathrm{~V} v s \mathrm{RHE} \quad \text { (Eq2) } \\
& \mathrm{BH}_{4}^{-}+2 \mathrm{H}_{2} \mathrm{O} \rightarrow \mathrm{BO}_{2}^{-}+4 \mathrm{H}_{2}
\end{aligned}
$$

$\mathrm{Ni}$ has been considered as a BOR catalyst by several groups (see e.g. Refs [2-10] and refs therein). However, the results were rather contradictory, some papers claiming high, the other - low BOR activity of Ni. Recently we have demonstrated [11] that the BOR activity of $\mathrm{Ni}$ is strongly dependent on its surface state (metallic $v$ s oxidized). Metallic Ni, with its low HER activity [12,13], appeared to be an excellent BOR catalyst ensuring a low open-circuit potential (OCP) and enabling net BOR current below $E=0 \mathrm{~V} v s$ RHE. Density functional theory (DFT) calculations suggest that the high BOR activity at low potentials is due to a better balance in the adsorption energies of $\mathrm{H}_{\mathrm{ad}}$, $\mathrm{OH}_{\mathrm{ad}}$, and B-containing reactive intermediates, compared to $\mathrm{Pt}$ and $\mathrm{Au}$ surfaces. Indeed, $\mathrm{BH}_{4}{ }^{-}$ adsorption on $\mathrm{Ni}$ being weaker than on $\mathrm{Pt}$, it limits surface blocking by $\mathrm{BH}_{\mathrm{ad}}$, but stronger than on $\mathrm{Au}$, thus resulting in a faster BOR kinetics $[11,14]$. Later Braesch et al. $[15,16]$ have successfully demonstrated that DBFC anodes made from Ni enable higher power densities and cell voltages than equivalent DBFCs with Pt of Pd-based anodes. However, Ni-based anodes do not enable to completely valorize the $\mathrm{BH}_{4}^{-}$fuel, as only four electrons per $\mathrm{BH}_{4}^{-}$species are produced in the anode reaction, the other four being lost into $\mathrm{H}_{2}$ that escapes the cell. This could be ascribed to metallic Ni being poor hydrogen oxidation reaction (HOR) catalyst, a downside of its advantages.

The present contribution attempts to provide further insights into the mechanisms of the BOR at Ni surfaces. Applying operando Fourier-Transform Infrared spectroscopy (FTIRS) and online differential electrochemical mass spectrometry (DEMS), products and eventual intermediates of the BOR on $\mathrm{Ni}$ are detected; it will notably be shown that $\mathrm{H}_{2}$ has two origins: HER from cathodic reduction of the solvent - water, and catalytic decomposition/dissociative adsorption of the $\mathrm{BH}_{4}{ }^{-}$ species at the Ni surface. Supplement experimental data with the DFT calculations combined with these spectroscopic/metric evidences enable to shed light on the BOR mechanism on Ni.

\section{Experimental and computational details}


Materials. Two types of the $\mathrm{Ni}$ working electrodes (WE) were utilized in this work. Electrochemical (EC) and FTIRS measurements were performed with a polycrystalline Ni disk purchased from MaTeck $(99.99 \% \mathrm{Ni}, \varnothing 5 \mathrm{~mm}$ for electrochemical and $\varnothing 10 \mathrm{~mm}$ for FTIRS). The top surface of the $\mathrm{Ni}$ disk (in what follows addressed as $\mathrm{Ni}_{\text {poly }}$ ) was thoroughly polished with an $\mathrm{Al}_{2} \mathrm{O}_{3}$ slurry with size of the granules from 1.0 down to $0.3 \mu \mathrm{m}$ (Alfa Aesar) and then sonicated in ethanol (5 min.) and water (10 min.). For electrochemical and FTIRS measurements, the $\mathrm{Ni}_{\text {poly }}$ rod or disk were fixed either in a holder or on top of a glass tube, respectively, and their lateral surface was sealed with a Teflon tape so that only the flat top surface of the electrode was accessible to the electrolyte. Prior to each measurement (i.e. acquisition of a cyclic voltammogram or a FTIR spectrum) the top surface of the $\mathrm{Ni}_{\text {poly }}$ fixed in the holder was additionally polished with an $\mathrm{Al}_{2} \mathrm{O}_{3}$ slurry $(0.3 \mu \mathrm{m}$, Alfa Aesar), rinsed with ultra-pure water $(18.2 \mathrm{M} \Omega \mathrm{cm}$, TOC < $3 \mathrm{ppb}$, Arium H2OPRO-UV-T-TOC or PURELAB Chorus 1) and sonicated (for $c a .1 \mathrm{~min}$ ) in ultra-pure water. Short polishing time and utilization of the $\mathrm{Al}_{2} \mathrm{O}_{3}$ granules with $0.3 \mu \mathrm{m}$ size allow to fully remove $\mathrm{Ni}$ oxides from the surface and thus achieve high reproducibility of the measurements. Ni felt from Sorapec was used as an electrode in the DEMS cell. Prior to the measurements it was subjected to an acid etching following the procedure detailed in Ref [15] to remove Ni oxides/hydroxides from its surface, and pressed between a PTFE membrane and a current collector. Some complementary experiments were performed with an Au disk (Ø8 mm, MaTeck, 99.99\%).

Electrochemical measurements. Electrochemical measurements were performed in $0.1 \mathrm{M} \mathrm{NaOH}$ electrolyte in a standard three-electrode cell (Pyrex glass) at room temperature $294 \pm 1 \mathrm{~K}$ using a Biologic SP-300 potentiostat. The electrolyte was prepared from $\mathrm{NaOH}$ solution $(50 \%$ in water, Premium quality, Aldrich) and ultra-pure water. The counter electrode (Pt wire) and the reference electrode $(\mathrm{Hg}|\mathrm{HgO}| 0.1 \mathrm{M} \mathrm{NaOH})$ compartments were connected with the working electrode chamber via a glass frit and a Luggin capillary, respectively. All electrode potentials reported in this paper are referred to the reversible hydrogen electrode (RHE). Prior to each experiment, the glassware was cleaned by soaking in a $\mathrm{H}_{2} \mathrm{SO}_{4}: \mathrm{H}_{2} \mathrm{O}_{2}(1: 1 \mathrm{v} / \mathrm{v})$ mixture and then thoroughly washed with ultra-pure water.

FTIRS measurements. Spectroelectrochemical measurements were performed at room temperature $(298 \pm 2 \mathrm{~K})$ under potentiostatic conditions using a Gamry Reference 600 potentiostat and a VERTEX 80v Brucker Fourier transform infrared spectrometer equipped with a MCT detector $\left(\mathrm{N}_{2}\right.$-liquid temperature) using a ZnSe prism. Three-electrode glass cell with $\mathrm{Pt}$ foil as a counter electrode and either reversible hydrogen, RHE, or $\mathrm{Hg} / \mathrm{HgO}\left(E_{\mathrm{Hg} / \mathrm{HgO}}=0.928 \mathrm{~V} v s \mathrm{RHE}\right)$ as a reference electrode was used for the measurements. The chamber was continuously purged with $\mathrm{N}_{2}$ in order to avoid any traces of $\mathrm{CO}_{2}$ from air which might affect the analysis. The spectra were collected in a double-sided acquisition mode between wavenumbers from 4000 to $700 \mathrm{~cm}^{-1}$ with a resolution of $4 \mathrm{~cm}^{-1}$. In order to obtain a single-beam spectrum, 256 interferograms were co-added and then Fourier transformed. For every single measurement a background spectrum was obtained at the open-circuit potential ( $E_{\mathrm{OC}}$ varying from -0.29 to $-0.23 \mathrm{~V} v s \mathrm{RHE}-$ in the presence of $\mathrm{NaBH}_{4}$ ) right before the start of the acquisition at a sample potential. In what follows all spectra are presented after subtraction of this background. In case of the spectra acquisition at the OCP as a function of time, the first spectrum was used as a background and subtracted from all the subsequent ones. Owing to this subtraction, negative-pointing peaks in the difference FTIR spectra 
indicate accumulation of the corresponding species in the thin layer trapped between the WE and the prism, while positive-pointing peaks reveal impoverishment of the thin layer in the respective species.

After immersion in the electrochemical cell and before the measurement of FTIR spectra, the $\mathrm{Ni}_{\text {poly }}$ electrode (in a meniscus configuration) was conditioned in a $\mathrm{N}_{2}$-saturated $0.1 \mathrm{M} \mathrm{NaOH}$ or $0.1 \mathrm{M}$ $\mathrm{NaOD}$ solution (prepared from $50 \% \mathrm{NaOH}$ solution in $\mathrm{H}_{2} \mathrm{O}$, premium quality, Aldrich; $40 \% \mathrm{NaOD}$ solution $\mathrm{D}_{2} \mathrm{O}, 99.5 \%$ Alfa Aesar) by cycling between, first, -0.20 and $0.40 \mathrm{~V}$, second, -0.06 and $0.40 \mathrm{~V}$ and, finally, -0.20 and $0.40 \mathrm{~V}$ vs RHE at a sweep rate $(v)$ of $20 \mathrm{mV} \mathrm{s}^{-1}$. The potential interval between -0.1 and $1.5 \mathrm{~V}$ vs RHE was used for conditioning the Au electrode. Then $2 \mathrm{M}$ $\mathrm{NaBH}_{4} / \mathrm{NaBD}_{4}$ (dissolved in $0.1 \mathrm{M} \mathrm{NaOH} / \mathrm{NaOD}$ ) was added to the cell in order to achieve final concentration of $0.2 \mathrm{M} \mathrm{NaBH}_{4} / \mathrm{NaBD}_{4}$. A typical protocol of electrochemical measurements during an operando FTIR measurements consisted in 1) recording 3 scans between -0.20 and 0.30 $\mathrm{V} v s \mathrm{RHE}, 2)$ applying potential equal to $E_{\mathrm{oc}}$ at which the $\mathrm{Ni}(\mathrm{Au})$ disk was pressed to the surface of the prism and a background spectrum was collected, 3 ) applying potential of interest $\left(E_{\mathrm{i}}=-0.25\right.$ $-0.4 \mathrm{~V} v s \mathrm{RHE}$ for $\mathrm{Ni}$ and $E_{\mathrm{i}}=-0.2-1.5 \mathrm{~V} v s$ RHE for $\mathrm{Au}$ ) at which a series of FTIR spectra (typically 11) was collected in order to see the dynamics of their evolution with time.

Reference solutions were prepared from $\mathrm{NaBH}_{4}\left(\mathrm{NaBD}_{4}\right), \mathrm{NH}_{3} \mathrm{BH}_{3}, \mathrm{H}_{3} \mathrm{BO}_{3}, \mathrm{NaBO}_{2}, \mathrm{~B}_{2} \mathrm{O}_{3}$ and $\mathrm{Na}_{2} \mathrm{~B}_{4} \mathrm{O}_{7}$ (all of the highest quality available and purchased either from Aldrich $\left(\mathrm{NaBH}_{4}\right.$ and $\left.\mathrm{NH}_{3} \mathrm{BH}_{3}\right)$ or Alfa Aesar) in $0.1 \mathrm{M} \mathrm{NaOH}(\mathrm{NaOD})$ or pure $\mathrm{H}_{2} \mathrm{O}\left(\mathrm{D}_{2} \mathrm{O}, 99.8 \%\right.$, Alfa Aesar). Spectra of the reference compounds were acquired in FTIR-ATR configuration with a hemispherical ZnSe prism.

DEMS Measurements. DEMS measurements were performed in order to measure the amount of hydrogen generated at a metallic Ni electrode during the BOR. A specifically designed 3-electrode electrochemical cell, inspired by Refs. [17-19], was used where the WE was placed at the bottom of the cell against PTFE membranes in order to ensure the smallest delay between the production and detection of the gaseous species. A freshly prepared RHE and a glassy carbon plate were used respectively as a reference and a counter electrode. In order to have high surface area of metallic $\mathrm{Ni}$, and thus ensure significant gas generation and high sensitivity of detection, the Ni disk was replaced by a Ni felt freshly etched in a mixture of strong acids (see Refs $[15,20]$ for the etching procedure). The electrical contact was made by using a Ni ring (previously electrochemically oxidized to limit its BOR contribution) pressed against the felt and connected to a $\mathrm{Ni}$ wire (similarly oxidized). This wire was placed in a glass tube purged with $\mathrm{Ar}$ in order to minimize contact of the wire with the electrolyte. The WE being placed at the bottom of the cell, controlling mass-transport to its surface is not trivial. To partially solve this issue, the end of the glass tube was placed as close to the WE as possible. In this manner, the Ar bubbles could create some convection in the vicinity of the WE. Unfortunately, the mass-transport could not be precisely controlled and the measurements were not performed in standard "Levich conditions". The DEMS cell was cleaned and prepared similarly as the ones presented above.

Because the BOR at low potentials occurs in competition with the HER, the $\mathrm{H}_{2}$ generation at the $\mathrm{Ni}$ electrode could arise from either of the two reactions. In order to separate these two contributions and provide unambiguous information regarding the hydrogen source required for 
the understanding of the BOR mechanism, the sodium borohydride was replaced by sodium borodeuteride $\left(\mathrm{NaBD}_{4}, 99 \%\right.$ (isotopic), Alfa Aesar) and was dissolved in $1 \mathrm{M} \mathrm{NaOH}$. In such a configuration, ionic currents corresponding to the three different masses could be detected by the mass spectrometer: $\mathrm{I}_{\mathrm{m} / \mathrm{z}=2}$ (corresponding to $\mathrm{H}_{2}$ originating from the $\mathrm{HER}$ ), $\mathrm{I}_{\mathrm{m} / \mathrm{z}=4}$ (corresponding to $\mathrm{D}_{2}$ originating from the $\mathrm{BOR}$ ), and $\mathrm{I}_{\mathrm{m} / \mathrm{z}=3}$ (corresponding to $\mathrm{HD}$, originating from recombination of $\mathrm{H}_{\mathrm{ad}}$ and $\mathrm{D}_{\mathrm{ad}}$ ). In order to estimate the number of electrons valorized during the BOR, the cell must be calibrated. To do so a cell constant was determined from the $\mathrm{m} / \mathrm{z}=2$ current measured while collecting cyclic voltammograms (CVs) in a supporting electrolyte. Fig. S1 shows the values of $\mathrm{I}_{\mathrm{f}}$ and $\mathrm{I}_{\mathrm{m} / \mathrm{z}=2}$ as well as the cell constant $\mathrm{K}$ and the resulting equivalent faradaic current, $\mathrm{I}_{\mathrm{H} 2 \text {,eq, }}$ obtained by correcting the ionic current by the constant. Because this calibration procedure depends of the area of the Ni electrode, it was performed for each WE. Once the ionic currents are calibrated into the equivalent current, the number of electrons valorized during the BOR can be estimated (Eq4):

$$
n=\frac{8 I_{\mathrm{f}}}{\frac{1}{2} I_{\mathrm{HD}}+I_{\mathrm{D}_{2}}+I_{\mathrm{f}}}
$$

$n$ - number of electrons per $\mathrm{BD}_{4}^{-}$species

$I_{\mathrm{f}}=$ Faradic current $(\mathrm{mA})$

$I_{\mathrm{HD}}=$ Calibrated ionic current of $\mathrm{HD}(\mathrm{mA})$

$I_{\mathrm{D} 2}=$ Calibrated ionic current of $\mathrm{D}_{2}(\mathrm{~mA})$

DFT Calculations. All calculations were performed using the ab initio total energy and moleculardynamics Vienna ab initio simulation program (VASP) developed at the Institute for Material Physics at the University of Vienna [21-23]. The electronic structure was represented using the projector augmented wave method [24,25], a plane wave basis set with a cut off energy of $450 \mathrm{eV}$, and the Perdew-Wang form of the generalized gradient approximation [26]. A 5 x 5 x 1 MonkhorstPack k-point mesh was used for sampling the Brillouin zone and performing unrestricted (spin polarized) calculations. Harmonic vibrational modes were calculated and used for zero-point vibrational energy (ZPVE) corrections to the adsorbate energies. Transition states searches were performed using the climbing image nudged elastic band method (CI-NEB). A (111) surface was used to represent the nickel surface. The Ni(111) surface was modeled with a 4 layer slab with the two bottom layers constrained to nickel fcc lattice positions and the two top layers allowed to relax. A 3 x 3 surface cell was used. A surface coverage of 1 adsorbate molecule per 9 surface atoms was used to calculate the energetics on the reaction intermediates, unless otherwise specified. A vacuum region of $15 \AA$ was inserted between the periodic surface slabs. Binding energies and reaction energies were calculated using the same approach as our prior work examining borohyride electrooxidation on other late transition metal surfaces [27].

\section{Results and discussion}

\subsection{Electrochemistry}


Fig. 1 shows $\mathrm{CV}$ s of a polished $\mathrm{Ni}_{\text {poly }}$ rod in $\mathrm{NaOH}$ solutions in the absence and in the presence of $\mathrm{NaBH}_{4}$. The shape of the $\mathrm{CV}$ in the $0.1 \mathrm{M} \mathrm{NaOH}$ supporting electrolyte (Fig. 1a) confirms that the surface of the electrode is essentially metallic. Indeed, it has been demonstrated [12,28] that presence of surface (hydr)oxides significantly modifies the shape of the $\mathrm{CV}$ of a Ni electrode (i.e. an additional anodic peak appears at $E<0.15 \mathrm{~V} v s \mathrm{RHE}$ ), the latter could thus serve as a fingerprint of the surface state. The fact that the electrode is in its metallic state, is critically important, as it ensures the high BOR activity. One may notice that the OCP of the $\mathrm{Ni}_{\text {poly }}$ in $5 \mathrm{mM} \mathrm{NaBH}_{4}$ (Fig $1 b)$ is equal to $E=-0.257 \mathrm{~V}$ vs RHE, at higher $\mathrm{NaBH}_{4}$ concentrations lying between $-0.25<E<$ $-0.28 \mathrm{~V} v s$ RHE (Fig. S2). These values are very similar to those observed for Ni nanoparticles electrodeposited on carbon, $\mathrm{Ni}_{\mathrm{ED}} / \mathrm{C}\left(E=-0.235 \mathrm{~V}\right.$ vs RHE in $5 \mathrm{mM} \mathrm{NaBH}_{4}+1 \mathrm{M} \mathrm{NaOH}$, see curve 3 in Fig. 1b replotted from our previous publication [11]). The OCP value of the $\mathrm{Ni}_{\text {poly }}$ is significantly lower than that of either polycrystalline $\mathrm{Pt}(E \approx 0 \mathrm{~V} v s \mathrm{RHE}$ [29]) or partially oxidized $\mathrm{Ni}(E=-0.152 \mathrm{~V}$ vs RHE [11]), which goes along with the higher HER activity of the latter [13]. One might notice however different shapes of $\mathrm{CVs}$ for $\mathrm{Ni}_{\text {poly }}$ and $\mathrm{Ni}_{\mathrm{ED}} / \mathrm{C}$ in the presence of $\mathrm{NaBH}_{4}$. While for $\mathrm{Ni}_{\mathrm{ED}} / \mathrm{C}$, the faradaic current reached the mass-transport-limited value already at $c a$. $E=$ $-0.1 \mathrm{~V}$ vs RHE (for $5 \mathrm{mM} \mathrm{NaBH}_{4}$ ), no mass-transport-limited current was achieved for the $\mathrm{Ni}_{\text {poly }}$ electrode. This difference may be explained by a lower number of the available surface sites on the $\mathrm{Ni}_{\text {poly }}$ rod compared to that of the $\mathrm{Ni}$ ED/C electrode. The calculation of the electrochemically active surface area, ECSA, of $\mathrm{Ni}$ by integrating anodic peaks in $\mathrm{CV}$ s obtained in $\mathrm{NaOH}$ solution (Fig. 1a) and using $0.514 \mathrm{mC} \mathrm{cm}^{-2}$ conversion coefficient [30] gives values of $0.26 \pm 0.01$ and 14 $\pm 1 \mathrm{~cm}^{2}$ for $\mathrm{Ni}_{\text {poly }}$ rod and the $\mathrm{Ni}_{\mathrm{ED}} / \mathrm{C}$ electrode, respectively. This significantly smaller ECSA of the $\mathrm{Ni}_{\text {poly }}$ electrode results in its higher surface coverage with the surface intermediates, in other words, higher surface 'poisoning'. Indeed, even if the surface 'poisoning' effect on Ni electrodes is much less pronounced than that on the Pt ones [29,31], it cannot be fully discarded. This surface poisoning manifests itself in the positive shift of the BOR currents with the $\mathrm{BH}_{4}{ }^{-}$concentration seen in Fig. 1c as well as in the increase of the OCP value at high $\mathrm{BH}_{4}{ }^{-}$concentration (Fig. S2). Other conditions being equal, the extent of 'poisoning' is determined by the ratio between the concentration of $\mathrm{BH}_{4}{ }^{-}$and the number of the adsorption sites on the electrode surface, and this applies both to Pt [32] and to Ni [15] electrodes.

\section{Fig. 1 here}

Along with the number of the active sites and the $\mathrm{BH}_{4}{ }^{-}$concentration, the anodic potential limit is a factor that strongly affects the BOR. CVs represented in panel (d) of Fig. 1 demonstrate that increasing the electrode potential beyond $c a$. $0.2 / 0.3 \mathrm{~V}$ ss $\mathrm{RHE}$ (depending on the $\mathrm{BH}_{4}^{-}$ concentration) results in a current decrease down to a very low value. Comparison of CVs in the presence and in the absence of $\mathrm{BH}_{4}{ }^{-}$indicates that this current decay at positive potentials is due to the surface $\alpha-\mathrm{Ni}(\mathrm{OH})_{2}$ formation, the latter being inactive towards the BOR. Potential reversal from $0.4 \mathrm{~V}$ down to $c a$. $0.1 / 0.2 \mathrm{~V}$ vs $\mathrm{RHE}$ (depending on the $\mathrm{BH}_{4}{ }^{-}$concentration) results in regeneration of the BOR currents, due to the electrochemical reduction of the electrode surface ( $c f$.

Fig 1a). It should be noted that further increase of the anodic potential limit leads to an irreversible 
loss of a significant part of the BOR activity [11], which can be explained by the resistance of the formed $\beta-\mathrm{Ni}(\mathrm{OH})_{2} / \mathrm{NiO} / \mathrm{NiOOH}$ towards electrochemical reduction at room temperature unless very high cathodic polarization is applied [33,34].

Thus, electrochemical measurements confirm that BOR is catalyzed by Ni in the interval of low potentials $(-0.25<E<0.4 \mathrm{~V} v s$ RHE), while on Pt anodic BOR currents can only be observed at $E>0 \mathrm{~V} v s$ RHE, because of the high activity of the latter in the HER.

\subsection{FTIRS}

Fig. 2 shows the temporal evolution of the FTIR spectra of a $\mathrm{Ni}_{\text {poly }}$ disc in a $0.2 \mathrm{M} \mathrm{NaBH}_{4}+0.1$ $\mathrm{M} \mathrm{NaOH}$ solution at two electrode potentials: $E_{\mathrm{OC}}=-0.23 \mathrm{~V}$ vs RHE and $E=0.2 \mathrm{~V}$ vs RHE. Because of the subtraction of the background spectrum, positive-pointing absorption peaks correspond to the species whose concentration decreases with time, while negative-pointing peaks correspond to those whose concentration increases with time. Consumption of $\mathrm{BH}_{4}^{-}$can be clearly observed already at the OCP $\left(E_{\mathrm{OC}}=-0.23 \mathrm{~V} v s \mathrm{RHE}\right)$ from the growth of the intensity of the stretching $(v(\mathrm{~B}-\mathrm{H}))$ and bending $(\delta(\mathrm{B}-\mathrm{H}))$ modes of the B-H bond at 2260 and at $1100 \mathrm{~cm}^{-1}$, respectively ( $c f$. positive-pointing peaks in Fig. 2a). This is accompanied by the emergence of two negative-pointing absorption peaks, at $1080 \mathrm{~cm}^{-1}$ and at $960 \mathrm{~cm}^{-1}$. At higher potential above $0 \mathrm{~V}$ vs RHE (as an example Fig. 2b shows data for $E=0.2 \mathrm{~V} v s$ RHE), the FTIR spectra change drastically: instead of the $1080 \mathrm{~cm}^{-1}$ and $960 \mathrm{~cm}^{-1}$ absorption bands, one may observe appearance of the bands at $1415,1320,1150$ and $1030 \mathrm{~cm}^{-1}$. Potential reversal to the OCP results in the resurgence of the absorption bands at 1150 and $960 \mathrm{~cm}^{-1}$. The influence of the electrode potential on the in situ FTIR spectra can be clearly observed from Fig. 3a.

Fig. 2 here

Infra-red spectroscopy has been widely applied in the past for studies of boron compounds and their complex equilibria in aqueous solutions. Electrochemical BOR has been investigated with in situ FTIRS (in the external reflection configuration) on Pt [35], $\mathrm{Au}$ [36,37], $\mathrm{Cu}-\mathrm{Ag}$ [38,39], Pd [40] and $\mathrm{Ni}[6]$, whereby some of the absorption bands observed in this work have also been documented. It should be noted however that the assignment of the absorption peaks is not unambiguous. This is due to the presence of numerous absorption bands with similar frequencies, which might correspond to vibrations of different bonds $(\mathrm{B}-\mathrm{H}, \mathrm{B}-\mathrm{O}(\mathrm{H}), \mathrm{B}-\mathrm{O}-\mathrm{B})$. Note also that borates in aqueous solutions are subject to complex acid-base and polymerization equilibria, resulting in $\mathrm{pH}$ and concentration dependence of the vibrational spectra. To help the assignment, in situ FTIRS measurements have been performed with $\mathrm{NaBD}_{4}$ in $\mathrm{NaOD}+\mathrm{D}_{2} \mathrm{O}$ and $\mathrm{NaOH}+\mathrm{H}_{2} \mathrm{O}$. Furthermore, FTIR spectra were acquired for a series of $\mathrm{H}$ and $\mathrm{D}$-substituted reference compounds. The spectra of reference compounds are shown in Fig. 4, while the assignment of the observed vibrations is provided in Table $\mathbf{1}$. 
Fig. 3 here

Table 1 here

One may see that in situ FTIR spectra of the BOR on metallic Ni acquired at $E<0 \mathrm{~V} v s$ RHE closely resemble the reference spectrum of $\mathrm{NaBO}_{2}$ in $\mathrm{NaOH}$, with its two broad absorption features at 1150 and $935 \mathrm{~cm}^{-1}$. According to the literature data [41], the observed spectral features are indicative of the presence of tetrahedral $\mathrm{B}(\mathrm{OH})_{4}{ }_{4}^{-}$ions with 1150 and $935 \mathrm{~cm}^{-1}$ peaks corresponding to the asymmetric stretching of the $\mathrm{B}-\mathrm{OH}$ and to the $\mathrm{B}-\mathrm{O}-\mathrm{H}$ bending. The $1150 \mathrm{~cm}^{-1}$ peak is very broad, which may be attributed to the formation of polyborates due to the tendency of metaborate to polymerize in aqueous solutions at concentrations above $50 \mathrm{mM}[42,43]$. In $\mathrm{NaOD}+\mathrm{D}_{2} \mathrm{O}$, both peaks shift to lower frequencies $\left(1030\right.$ and $\left.835 \mathrm{~cm}^{-1}\right)$. The red-shift of the two peaks upon H/D substitution suggests that the $\mathrm{B}-\mathrm{OH}$ stretching not only involves elongation/contraction of the B$\mathrm{O}$ bond but also displacement of $\mathrm{H}(\mathrm{D})$. Formation of $\mathrm{B}(\mathrm{OH})_{4}^{-}$(the final product of the BOR) at the $\mathrm{Ni}$ electrode already at $E_{\mathrm{OC}}=-0.23 \mathrm{~V} v s \mathrm{RHE}$ is remarkable, confirming the exceptional activity of metallic $\mathrm{Ni}$ for this reaction [11]. It is worth mentioning that the 1150 and $935 \mathrm{~cm}^{-1}$ vibrations have been observed in previous studies of the BOR on Pd, Pt and Au electrodes, but attributed to various reaction intermediates rather than to the BOR product.

Fig. 3 shows that increasing the electrode potential results in a gradual disappearance of the spectral features of tetrahedral $\mathrm{B}(\mathrm{OH})_{4}^{-}$. Instead, peaks at 1415 and $1155 \mathrm{~cm}^{-1}$, characteristic of the $\mathrm{C}_{3 \mathrm{v}}$ symmetry of $\mathrm{B}(\mathrm{OH})_{3}$, emerge, as confirmed by the reference spectra of $\mathrm{H}_{3} \mathrm{BO}_{3}$ and $\mathrm{B}_{2} \mathrm{O}_{3}$ solutions (Fig. 4). H/D substitution results in their red-shift to 1380 and $890 \mathrm{~cm}^{-1}$, confirming that the former corresponds to the $\mathrm{B}-\mathrm{OH}$ stretching, while the latter to the $\mathrm{B}-\mathrm{O}-\mathrm{H}$ bending vibration. Formation of $\mathrm{B}(\mathrm{OH})_{3}$ rather than $\mathrm{B}(\mathrm{OH})_{4}{ }^{-}$at $E>0 \mathrm{~V}$ vs $\mathrm{RHE}$ can be attributed to the acid-base equilibrium (Eq5) established in the thin layer trapped between the surface of the Ni electrode and the $\mathrm{ZnSe}$ prism.

$\left(\mathrm{B}(\mathrm{OH})_{3}+2 \mathrm{H}_{2} \mathrm{O} \rightleftharpoons\left[\mathrm{B}(\mathrm{OH})_{4}\right]^{-}+\left[\mathrm{H}_{3} \mathrm{O}\right]^{+} ; \mathrm{pK}_{\mathrm{a}}=8.9-9.2[44]\right.$

To verify this, spectra of boric acid in water $(\mathrm{pH} \approx 5.5)$ and in $\mathrm{NaOH}$ of varied concentrations were acquired. Fig. 4d shows that, as the concentration of $\mathrm{NaOH}$ increases, peaks at 1415 and $1155 \mathrm{~cm}^{-}$ ${ }^{1}$ corresponding to the $\mathrm{C}_{3 \mathrm{v}}$ symmetry of $\mathrm{B}(\mathrm{OH})_{3}$ gradually disappear, while peaks corresponding to tetrahedral symmetry of $\mathrm{B}(\mathrm{OH})_{4}{ }^{-}$emerge. In $0.1 \mathrm{M} \mathrm{NaOH}$ one may also observe vibrational peak at $1320 \mathrm{~cm}^{-1}$, which however disappears at higher $\mathrm{NaOH}$ concentrations. This behavior allows to attribute the latter peak to $\mathrm{B}-\mathrm{O}-\mathrm{B}$ vibrations in polymeric $\mathrm{B}_{\mathrm{x}} \mathrm{O}_{\mathrm{y}} \mathrm{H}_{\mathrm{z}}$ species. Indeed, it is known that the extent of polymerization of borates strongly depends on the $\mathrm{pH}$. At high $\mathrm{pH}$, solutions are dominated by $\mathrm{B}(\mathrm{OH})_{4}^{-}$species, at low $\mathrm{pH}$ by $\mathrm{B}(\mathrm{OH})_{3}$, while the concentration of di, tri-, and tetramers is the highest at intermediate $\mathrm{pH}$ values (between 7 and 12) [45]. The peak at $1320 \mathrm{~cm}^{-1}$ was also detected during in situ FTIRS measurements at $E>0 \mathrm{~V}$ vs RHE both in $\mathrm{NaOH}$ $+\mathrm{H}_{2} \mathrm{O}$ and $\mathrm{NaOD}+\mathrm{D}_{2} \mathrm{O}$. The fact that H/D substitution does not lead to a red-shift of the 1320 
$\mathrm{cm}^{-1}$ peak is in agreement with its assignment to the B-O-B bond vibrations. Thus, FTIRS data evidence formation of the $\mathrm{B}(\mathrm{OH})_{4}{ }^{-}$on Ni starting from the $\mathrm{OCP}$ and its transformation into $\mathrm{B}(\mathrm{OH})_{3}$ and polyborates following changes in the interfacial $\mathrm{pH}$ when the conversion rate of $\mathrm{BH}_{4}{ }^{-}$to its final product (that consumes $\mathrm{OH}^{-}$) increases. Note that at the $\mathrm{OCP}$ the interfacial $\mathrm{pH}$ does not change even at long reaction times ( $c f$. Fig 2a), since the $\mathrm{OH}^{-}$consumption of the anodic BOR (Eq.1/1*) is counterbalanced by the $\mathrm{OH}^{-}$formation of the cathodic HER (Eq.2). However, at potential values positive of the OCP the anodic current dominates, the $\mathrm{OH}^{-}$consumption of the anodic BOR resulting in an interfacial $\mathrm{pH}$ decrease. Such a behavior is accentuated by the high (equal to 2 in this work) $\mathrm{NaBH}_{4}$ to $\mathrm{NaOH}$ concentration ratio (dictated by the instability of the $\mathrm{ZnSe}$ prism at high $\mathrm{NaOH}$ concentration and by insufficient infra-red signal-to-noise ratio at low $\mathrm{NaBH}_{4}$ concentration), but may occur even in more concentrated $\mathrm{NaOH}$, especially at longer reaction times.

The in situ FTIR spectra of this work do not provide any evidence regarding the formation of soluble BOR intermediates, such as $\mathrm{BH}_{3} \mathrm{OH}^{-}$suggested during the $\mathrm{BOR}$ on $\mathrm{Pt}$ and $\mathrm{Au}$ [46]. The fact that dissolved intermediates are not observed indicates that they either do not desorb or rapidly readsorb and react on the electrode surface. It must also be noted that, according to the rotatingring disc studies of the $\mathrm{BOR}$ on $\mathrm{Pt}$ and $\mathrm{Au}$ [46] the amount of $\mathrm{BH}_{3} \mathrm{OH}^{-}$species escaping the working electrode is small and thus might not be detectable by the FTIRS. Indeed, spectra acquired under similar conditions during the BOR on an Au disk electrode did not show any straightforward sign of the $\mathrm{BH}_{3} \mathrm{OH}^{-}$species either (Fig. S3).

Fig. 4 here

To provide complementary information regarding the vibrational signature of $\mathrm{BH}_{3} \mathrm{OH}^{-}$as well as the reactivity of $\mathrm{Ni}$ towards the latter, ammonia-borane $\left(\mathrm{NH}_{3} \mathrm{BH}_{3}\right)$ oxidation was studied on the $\mathrm{Ni}$ disk using in situ FTIRS (Fig. 3d). It is known that $\mathrm{NH}_{3} \mathrm{BH}_{3}$ in water is subject to homogeneous hydrolysis which is believed to result in the formation of $\mathrm{BH}_{3} \mathrm{OH}^{-}$and $\mathrm{NH}_{4}{ }^{+}[47,48]$. The latter are confirmed by the spectra of the $\mathrm{NH}_{3} \mathrm{BH}_{3}$ reference acquired in $\mathrm{NaOH}$ and $\mathrm{NaOD}$ electrolyte (Fig. 4), where the peak at $1175 \mathrm{~cm}^{-1}$ likely corresponds to the $\mathrm{B}-\mathrm{OH}$ vibration in $\mathrm{BH}_{3} \mathrm{OH}^{-}$. The band is observed in the same spectral range as $\mathrm{B}-\mathrm{OH}$ in $\mathrm{B}(\mathrm{OH})_{4}^{-}$, but the latter is much broader, which is not surprising considering the tendency of borates to polymerize. Fig. 3d indicates that $\mathrm{NH}_{3} \mathrm{BH}_{3}$ oxidation on $\mathrm{Ni}$ starts at even lower potentials than the BOR $\left(E_{\mathrm{OC}}=-0.29 \mathrm{~V} v s \mathrm{RHE}\right)$. In addition to the appearance of $\mathrm{B}-\mathrm{OH}$ and $\mathrm{B}-\mathrm{O}-\mathrm{B}$ vibrations characteristic of the formation of $\mathrm{B}(\mathrm{OH})_{4}^{-}$, $\mathrm{B}(\mathrm{OH})_{3}$ and polyborates, as discussed above for the $\mathrm{BOR}$ on $\mathrm{Ni}$, one may notice a negative pointing peak around $1175 \mathrm{~cm}^{-1}$, which suggests disappearance of $\mathrm{BH}_{3} \mathrm{OH}^{-}$and its transformation in $\mathrm{B}(\mathrm{OH})_{4}{ }^{-}$and $\mathrm{B}(\mathrm{OH})_{3}$ during the ammonia-borane oxidation.

If the accumulation of the $\mathrm{BH}_{3} \mathrm{OH}^{-}$intermediate during the $\mathrm{BOR}$ occurred in significant quantities, then its formation could also be detected thanks to $\mathrm{B}-\mathrm{H}$ vibrations, which are quite different in $\mathrm{BH}_{4}{ }^{-}$and $\mathrm{BH}_{3} \mathrm{OH}^{-}$species (Fig. 4). However, analysis of the FTIR spectra during the BOR does not show any sign of the $\mathrm{BH}_{3} \mathrm{OH}^{-}$formation either in the $\mathrm{B}-\mathrm{OH}$ or $\mathrm{B}-\mathrm{H}$ vibrational interval. It is the high activity of $\mathrm{Ni}$ towards $\mathrm{BH}_{3} \mathrm{OH}^{-}$oxidation which is likely to explain why this species could not be observed during the $\mathrm{BOR}$ on $\mathrm{Ni}$. Thus, even if one cannot rule out formation of the $\mathrm{BH}_{3} \mathrm{OH}^{-}$ intermediate during the BOR on $\mathrm{Ni}$, its escape from the surface into the electrolyte is expected to be minor due to its fast oxidation on the Ni surface. 
Finally, it is instructive to compare FTIR spectra during the $\mathrm{NaBH}_{4}$ and $\mathrm{NaBD}_{4}$ oxidation, when both are performed in $\mathrm{NaOH}+\mathrm{H}_{2} \mathrm{O}$ (Fig. 3a and 3c). Remarkable similarity of this set of spectra and absence of peaks corresponding to vibrations of either H-O-D or D-O-D suggest that neither $\mathrm{D}_{2} \mathrm{O}$ nor HOD is formed during the $\mathrm{NaBD}_{4}$ oxidation on $\mathrm{Ni}\left(c f . \mathrm{Eq} 1^{*}\right)$, which is consistent with the low activity of metallic Ni in the HOR. We will come back to this issue in the next section, when discussing the differential electrochemical mass spectrometry (DEMS) data.

\subsection{DEMS}

DEMS measurements have been performed in order to detect eventual formation of hydrogen during the borohydride oxidation on $\mathrm{Ni} . \mathrm{NaBD}_{4}$ was used instead of $\mathrm{NaBH}_{4}$ to differentiate between hydrogen formation from borohydride and water (especially for $E<0 \mathrm{~V} v s$ RHE). Fig. 5 shows faradaic and MS ionic currents (recalculated into the faradaic current using calibration procedure described in Section 2) during the BOR (only anodic sweeps are shown, for full cycles the reader should refer to Fig. S4) on an etched Ni felt acquired in a linear potential sweep and corresponding to the formation of $\mathrm{H}_{2}, \mathrm{HD}$ and $\mathrm{D}_{2}$. The noise visible in the MS currents results from bubbles blocked in the pores of the Ni felt electrode and released randomly. The OCP value observed in the DEMS cell was somewhat higher than in the electrochemical cell ( $c f$. Fig. 1), especially at low $\mathrm{NaBH}_{4}$ concentration, which may be attributed to the presence of some (hydr)oxides on the surface of the Ni felt (since some oxidized patches might persist on the surface after the etching procedure).

Let us start the discussion with the analysis of the data in $50 \mathrm{mM} \mathrm{NaBD}_{4}$ (Figs. 5b,c,d). One may see that at $E>0 \mathrm{~V} v s \mathrm{RHE}$, the $\mathrm{D}_{2}$ evolution current closely matches the faradaic one, suggesting that the BOR on Ni occurs in an overall $4 \mathrm{e}^{-}$process. The other $4 \mathrm{e}^{-}$are released in the form of two $\mathrm{D}_{2}$ molecules per $\mathrm{BD}_{4}{ }^{-}$species and thus are not valorized (Eq6):

$$
\mathrm{BD}_{4}^{-}+4 \mathrm{OH}^{-} \rightarrow \mathrm{B}(\mathrm{OH})_{4}^{-}+2 \mathrm{D}_{2}+4 \mathrm{e}^{-}
$$

This conclusion agrees with the FTIRS measurements (lack of vibrations characteristic of either $\mathrm{D}_{2} \mathrm{O}$ or HOD during the $0.2 \mathrm{M} \mathrm{NaBD}_{4}$ oxidation in $0.1 \mathrm{NaOH}$ in $\mathrm{H}_{2} \mathrm{O}$ ). The amount of $\mathrm{HD}$ detected at $E>0 \mathrm{~V} v s \mathrm{RHE}$ in $50 \mathrm{mM} \mathrm{NaBD}_{4}$ is small confirming the above conclusion. At potentials below $E=0 \mathrm{~V}$ vs RHE, noticeable $\mathrm{H}_{2}$ evolution currents are detected, which correspond to the HER, the latter on Ni occurring through a Volmer (Eq7)-Heyrovsky (Eq8) mechanism [12,28,49].

$$
\begin{array}{ll}
\mathrm{H}_{2} \mathrm{O}+\mathrm{e}^{-}=\mathrm{H}_{\mathrm{ad}}+\mathrm{OH}^{-} & \text {(Eq7, Volmer step) } \\
\mathrm{H}_{\mathrm{ad}}+\mathrm{H}_{2} \mathrm{O}+\mathrm{e}^{-}=\mathrm{H}_{2}+\mathrm{OH}^{-} & \text {(Eq8, Heyrovsky step) }
\end{array}
$$

While $\mathrm{H}_{\mathrm{ad}}$ formation via the Volmer step ( $\mathrm{Eq} 7$ ) occurs at potentials below $E=0 \mathrm{~V} v s$ RHE, it is likely to persist on the surface even at $E>0 \mathrm{~V} v s \mathrm{RHE}$ due to its strong adsorption on metallic Ni $[28,50]$. In the meantime, chemical recombination of hydrogen atoms (Tafel step, Eq9) is slow due to the strong adsorption of $\mathrm{H}_{\mathrm{ad}}$ on the surface of metallic Ni.
$\mathrm{H}_{\mathrm{ad}}+\mathrm{H}_{\mathrm{ad}}\left(\mathrm{D}_{\mathrm{ad}}\right)=\mathrm{H}_{2}(\mathrm{HD})$
(Eq9, Tafel step) 
While at $E>0 \mathrm{~V}$ vs RHE and high $\mathrm{BD}_{4}{ }^{-}$concentration $(50 \mathrm{mM})$ the HD formation currents are significantly inferior of those corresponding to the $\mathrm{D}_{2}$ formation, this is not the case at $E<0 \mathrm{~V} v s$ RHE and low $(5 \mathrm{mM}) \mathrm{BD}_{4}{ }^{-}$concentration (Fig. 5a), whereby $I_{\mathrm{D} 2}$ and $I_{\mathrm{HD}}$ become comparable. Formation of HD during the BOR points to the likely B-D (B-H) bond dissociation on the Ni surface with formation of a $D_{a d}$ intermediate in this potential range. It should however be noted that $\mathrm{D}_{\mathrm{ad}}$ could also originate from $\mathrm{D}_{2}$ (released during the $\mathrm{BD}_{4}{ }^{-}$oxidation) re-adsorption on $\mathrm{Ni}$. As mentioned above, this $\mathrm{HD}_{\mathrm{ad}}$ formation could only be observed either at low electrode potentials or low $\mathrm{BD}_{4}^{-}$concentration, suggesting that dissociation of $\mathrm{BD}_{4, \mathrm{ad}}$ on the surface of $\mathrm{Ni}$ is potentialactivated.

\section{Fig. 5 here}

Finally, the number of electrons $n$ produced during the BOR was estimated (Eq4, see Experimental Section) using the DEMS data and plotted in Fig.6. The estimation was made with and without consideration of the HD contribution to follow its impact. At high $\mathrm{BD}_{4}{ }^{-}$concentration $n$ is comprised between 4 and 5. Including the HD contribution in the calculation decreases the number of electrons by almost 1 at low potentials but has minor influence at $E>0.1 \mathrm{~V} v s \mathrm{RHE}$, as expected from the discussion above. It is interesting to note that, at low $\mathrm{BD}_{4}{ }^{-}$concentration, $n$ noticeably increases at $E>0.1 \mathrm{~V}$ vs RHE, that is in the potential interval where $\mathrm{OH}$ adsorption and $\mathrm{Ni}(\mathrm{OH})_{2}$ formation occur on the Ni surface. This may be attributed to the (i) potential-dependent rate of the Volmer step and (ii) its acceleration in the presence of (hydr)oxides on the Ni surface [12,49], both helping to better valorize $\mathrm{D}_{2}$ escaping during $\mathrm{BD}_{4}{ }^{-}$oxidation.

\section{Fig. 6 here}

\subsection{DFT}

Fig. 7 presents the borohydride oxidation energetics at 3 different potentials a) $E=-0.5 \mathrm{~V} v s$ RHE, b) $E=0 \mathrm{~V} v s \mathrm{RHE}$, and c) $E=0.5 \mathrm{~V} v s$ RHE. Energy of all states are related to the free energy of adsorbed $\mathrm{BH}_{4}{ }^{*}$ (where “*” denotes surface-bound species). Moving from left to right on the reaction energy diagram, each step represents a 1 electron oxidation elementary reaction, and the proton-electron pairs generated or water molecules consumed are left off the diagram. $E=-0.5 \mathrm{~V}$ vs RHE is slightly below the equilibrium oxidation potential of borohydride (Eq1), and Fig. 7a shows that all elementary oxidation steps are unfavorable. Based on the oxidation equilibrium potential ( $E=-0.41 \mathrm{~V}$ vs RHE), the overall oxidation of aqeuous borohydride to the final aqueous oxidation product would be uphill in energy $0.72 \mathrm{eV}$ at $E=-0.5 \mathrm{~V} v s$ RHE. The surface reaction is uphill by $2.19 \mathrm{eV}$ at this potential, due to both favorable initial oxidative adsorption of borohydride and favorable desorption of the final $\mathrm{B}(\mathrm{OH})_{3}{ }^{-}$product. This suggests an overpotential of $\sim 0.3 \mathrm{~V}$ would be necessary to make the surface catalytic reaction favorable on $\mathrm{Ni}(111)$, in good agreement with the experimentally observed OCP. 
Fig. 7 here

At $E=0 \mathrm{~V} v s \mathrm{RHE}$, all reaction intermediates are less stable than the final state $\mathrm{B}(\mathrm{OH})_{3}{ }^{*}$ adsorbate, and all oxidation steps are favorable or only slightly unfavorable. Presuming activation barriers correlate reasonably well with reaction energies, a significant oxidation current would be expected at $E=0 \mathrm{~V} v s$ RHE based on the DFT reaction energetics in good agreement with the experimental data. The preferred reaction path follows initial $\mathrm{B}-\mathrm{H}$ dissociation from $\mathrm{BH}_{4}^{*}$, followed by $\mathrm{BH}_{3}$ $\mathrm{OH}$ bond formation, successive $\mathrm{B}-\mathrm{H}$ dissociation to $\mathrm{BOH}^{*}$, then final $\mathrm{B}-\mathrm{OH}$ formations to the final product. Oxidation of $\mathrm{BH}_{3}{ }^{*}$ to $\mathrm{BH}_{2}{ }^{*}$ and $\mathrm{BH}_{3} \mathrm{OH}^{*}$ is slightly endothermic $(0.17 \mathrm{eV}$ and $0.06 \mathrm{eV}$, respectively). Also, $\mathrm{BOH}^{*}$ oxidation is slightly endothermic $(0.17 \mathrm{eV})$ at $0 \mathrm{~V}$ vs $\mathrm{RHE}$. At $E=0.5$ $\mathrm{V}$ vs RHE, all reaction steps are downhill from $\mathrm{BH}_{4}{ }^{*}$ to the final surface product of $\mathrm{B}(\mathrm{OH})_{3}{ }^{*}$ suggesting fast surface kinetics were the Ni surface to remain stable in metallic form at this high oxidation potential (but in practice $\mathrm{Ni}$ is covered by $\mathrm{OH}_{\mathrm{ad}} / \alpha-\mathrm{Ni}(\mathrm{OH})_{2}$ above $c a . E=0.2-0.25 \mathrm{~V}$ vs RHE, $c f$. Fig. 1a)

Table 2. here

Table 2 compares the desorption energies of closed-shell reaction intermediates with their surface oxidation elementary reaction energies at $E=0 \mathrm{~V}$ vs $\mathrm{RHE} . \mathrm{BH}_{3}, \mathrm{BH}_{2} \mathrm{OH}$ and $\mathrm{BH}(\mathrm{OH})_{2}$ are stable gas phase species that could possibly desorb from the surface as partial oxidation intermediates. Desorption of all these species is significantly more exothermic than oxidation reaction energies, suggesting further oxidation would be preferential and partial oxidation intermediates would not be observed in the fluid phase. $\mathrm{BH}_{3} *$ and $\mathrm{BH}_{2} \mathrm{OH}^{*}$ bind strongly to the $\mathrm{Ni}(111)$ surface and are highly unlikely to desorb. $\mathrm{BH}(\mathrm{OH})_{2}$ binding is relatively strong and the desorption reaction is endothermic, though desorption and oxidation would be competitive closer to the borohydride oxidation equilibrium potential. The preference for complete oxidation of B-containing intermediates agrees with the lack of FTIR observation of partial oxidation products.

Fig. 8 here

Fig. 8 illustrates the preferred adsorption configuration of reaction, transition state, and product for $\mathrm{BH}_{4}{ }^{*}$ dissociation on the $\mathrm{Ni}(111)$ surface.

$\mathrm{BH}_{4}{ }^{*} \rightarrow \mathrm{BH}_{3}{ }^{*}+\mathrm{H}^{*}$

Though the reaction energy diagrams in Fig. 7 treat $\mathrm{BH}_{4} *$ oxidation as directly producing a proton and electron pair, the hydridic nature of the B-bound hydrogen suggests B-H dissociation would occur, first, through a chemical step to produce $\mathrm{H}^{*}$ that could then subsequently oxidatively desorb (Volmer step, Eq7), or recombine with another $\mathrm{H}^{*}$ to form $\mathrm{H}_{2}$ (Tafel step, Eq9). The activation barrier for this initial B-H dissociation is $0.18 \mathrm{eV}\left(18.5 \mathrm{~kJ} \mathrm{~mol}^{-1}\right)$, suggesting that the nickel can 
effectively break B-H bonds, and a high surface coverage of $\mathrm{H}^{*}$ would be expected in the presence of borohydride solution at low potentials.

The competition between $\mathrm{H}^{*}$ oxidative desorption (Volmer step) and hydrogen evolution (Tafel step) would be potential dependent, as evolution is a chemical process whereas oxidation is an elementary electrochemical step. Fig. 9 illustrates the effect of surface coverage on the energetics of hydrogen evolution and oxidation at $\mathrm{Ni}(111)$ surface. At 1/9 monolayer of hydrogen, the hydrogen evolution is unfavorable by $0.34 \mathrm{eV}$. $\mathrm{H}^{*}$ oxidation is endothermic at potentials below at $E=0.34 \mathrm{~V}$ vs RHE. Such a low coverage of $\mathrm{H}^{*}$ would not motivate oxidation or hydrogen evolution over most of the potential range of interest. The adsorption of $\mathrm{H}^{*}$ is only slightly coverage dependent up to $1 \mathrm{ML}$, however, there is a step change in $\mathrm{H}^{*}$ stability above $1 \mathrm{ML}$. Fig 9b shows that at 10/9 monolayer of hydrogen, the evolution reaction is exothermic (reaction energy equals $-0.67 \mathrm{eV}$ ). Alternatively, the oxidation reaction is exothermic over the entire potential range of interest, and there will be a kinetic competition between $\mathrm{H}^{*}$ oxidation and evolution. Above 0 $\mathrm{V} v s$ RHE, oxidation of $\mathrm{H}^{*}$ becomes more favorable than the evolution reaction. Competition between the oxidation and evolution reactions dictates the Coulombic efficiency of borohydride oxidation. Note however that the above discussion is based on reaction energies (thermodynamic), not activation barriers (kinetics). Previous studies of the hydrogen electrode kinetics on $\mathrm{Ni}$ $[12,13,28,49]$ suggest that the hydrogen oxidation on Ni follows a Heyrovsky-Volmer mechanism, with the Volmer step being rate-determining. A small contribution of the Tafel step cannot be excluded close to $E=0 \mathrm{~V}$ vs RHE, but as soon as the potential is increased, the Heyrovsky-Volmer mechanism is dominating. Hence, studies of the hydrogen electrode kinetics on Ni also support faster Volmer compared to the Tafel step above $E=0 \mathrm{~V}$ ss RHE.

Though the reaction energies presented in Fig. 9 would suggest $\mathrm{H}^{*}$ oxidation will outcompete evolution as the potential is increased, we observe either no ( $c f$. Fig. 6b) or weak ( $c f$. Fig. 6a) increase in the oxidation efficiency at higher potentials experimentally. One of the possible explanations could be the influence of $\mathrm{H}_{\mathrm{ad}}, \mathrm{BH}_{4}$,ad and/or other $\mathrm{B}$-containing adsorbates on the borohydride (and on the hydrogen) oxidation kinetics. We leave this dilemma as a topic for future study.

Fig. 9 here

If the fed reactant is $\mathrm{BD}_{4}^{-}$, the relative coverage of $\mathrm{D}^{*}$ (from $\mathrm{B}-\mathrm{D}$ dissociation) and $\mathrm{H}^{*}$ (from the Volmer reaction) will be dictated by both potential and $\mathrm{BD}_{4}{ }^{-}$concentration. We considered direct $\mathrm{H}_{2}\left(\mathrm{D}_{2}\right)$ evolution from $\mathrm{BH}_{4} *$ (i.e., direct formation of $\mathrm{H}_{2}$ rather than formation of surface $\mathrm{H}^{*}$ ), and found an activation barrier of $1 \mathrm{eV}$ (Fig. S5). This high barrier relative to B-H dissociation suggests the relative ratio of $\mathrm{HD}$ and $\mathrm{D}_{2}$ evolved is dictated by the relative coverage of $\mathrm{H}^{*}$ and $\mathrm{D}^{*}$, and is in agreement with the experimental observation that higher $\mathrm{BD}_{4}{ }^{-}$concentrations (which would produce higher $\mathrm{D}^{*}$ coverages) decrease the fraction of HD formed. Finally, it should be emphasized that the kinetics of the $\mathrm{B}-\mathrm{H}$ dissociation might be influenced by the potential, the interfacial electric field, and the orientation of the surrounding water and $\mathrm{OH}^{-}$[51], the latter not considered within our DFT calculations. 


\section{Conclusions}

Metallic Ni is highly active towards the BOR at low potentials (around or below $0 \mathrm{~V} v s$ RHE). However, BOR on Ni produces 4 instead of $8 \mathrm{e}^{-}$in theory and is accompanied by $\mathrm{H}_{2}\left(\mathrm{D}_{2}\right.$ in case of $\mathrm{BD}_{4}^{-}$) formation, namely $2 \mathrm{D}_{2}$ molecules per $\mathrm{BD}_{4}^{-}$species, as evidenced by the online DEMS.

Along with the electrode potential, the BOR kinetics is strongly affected by the ratio of $\mathrm{BH}_{4}{ }^{-}$ concentration and the number of sites available on the Ni electrode surface. While increase of the $\mathrm{BH}_{4}^{-}$concentration results in the surface poisoning by the reaction intermediates, this effect is much less pronounced on $\mathrm{Ni}$ compared to either $\mathrm{Pt}$ or Pd electrodes. Operando FTIRS provides evidence for the formation of the final BOR product, $\mathrm{B}(\mathrm{OH})_{4}$, at potentials as low as $-0.23 \mathrm{~V} v \mathrm{~s}$ RHE, but no sign of soluble BOR intermediates in the whole potential interval studied (from -0.23 to $0.4 \mathrm{~V} v s \mathrm{RHE}$ ). The lack of FTIRS observation of partial oxidation products is corroborated by DFT calculations, the latter suggesting preference for complete oxidation of B-containing intermediates. In addition, the results of this work provide a warning regarding the interfacial $\mathrm{pH}$ change, which may occur in a thin layer upon infra-red spectroelectrochemical measurements in the external reflection configuration. In this work, such an interfacial $\mathrm{pH}$ change leads to a shift of the acid-based and polymerization equilibria resulting in the conversion of $\mathrm{B}(\mathrm{OH})_{4}{ }^{-}$into $\mathrm{B}(\mathrm{OH})_{3}$ and polyborates.

According to the DFT calculations, $\mathrm{BH}_{4}$ adsorbs molecularly on $\mathrm{Ni}(111)$ followed by a stepwise dissociation of the $\mathrm{B}-\mathrm{H}$ bond and formation of $\mathrm{B}-\mathrm{OH}$ bonds. The hydridic nature of the B-bound hydrogen suggests B-H dissociation would occur first through a chemical step to produce adsorbed hydrogen atoms that could then subsequently oxidatively desorb or recombine to form $\mathrm{H}_{2}$. Further studies are required to reconcile BOR accompanied by the hydrogen evolution on $\mathrm{Ni}$, slow hydrogen oxidation on metallic Ni evidenced from previous publications, and hydrogen formation via Volmer step during the BOR suggested by DFT calculations.

\section{Acknowledgments}

This work has been performed in the frame of the MobiDiC project, funded by the French National Research Agency (ANR, grant \# ANR-16-CE05-0009-01), and RSF Project No. 18-73-00143, funded by the Russian Science Foundation. 


\section{References}

[1] P.Y. Olu, N. Job, M. Chatenet, Evaluation of anode (electro)catalytic materials for the direct borohydride fuel cell: Methods and benchmarks, J. Power Sources. 327 (2016) 235257.

[2] H. Dong, R. Feng, X. Ai, Y. Cao, H. Yang, C. Cha, Electrooxidation mechanisms and discharge characteristics of borohydride on different catalytic metal surfaces, J. Phys. Chem. B. 109 (2005) 10896-10901.

[3] X. Geng, H. Zhang, W. Ye, Y. Ma, H. Zhong, Ni-Pt/C as anode electrocatalyst for a direct borohydride fuel cell, J. Power Sources. 185 (2008) 627-632.

[4] D. Zhang, K. Cheng, N. Shi, F. Guo, G. Wang, D. Cao, Nickel particles supported on multi-walled carbon nanotubes modified sponge for sodium borohydride electrooxidation, Electrochem. Commun. 35 (2013) 128-130.

[5] D.M.F. Santos, B. Šljukić, L. Amaral, D. Macciò, A. Saccone, C.A.C. Sequeira, Nickel and Nickel-Cerium Alloy Anodes for Direct Borohydride Fuel Cells, J. Electrochem. Soc. 161 (2014) F594-F599.

[6] V.O. Romanova, A. V Romanov, A. V Churikov, I.M. Gamayunova, M.A. Churikov, Electrochemical Oxidation of Borohydride-Ion on Nickel Electrode: a Study by the Method of IR-Spectroscopy (in Russ.), Electrochem. Energ. 14 (2014) 57-67.

[7] D. Zhang, G. Wang, Y. Yuan, Y. Li, S. Jiang, Y. Wang, K. Ye, D. Cao, P. Yan, K. Cheng, Three-dimensional functionalized graphene networks modified $\mathrm{Ni}$ foam based gold electrode for sodium borohydride electrooxidation, Int. J. Hydrogen Energy. 41 (2016) 11593-11598.

[8] S. Li, C. Shu, Y. Chen, L. Wang, A new application of nickel-boron amorphous alloy nanoparticles: anode-catalyzed direct borohydride fuel cell, Ionics (Kiel). 24 (2018) 201209.

[9] X. Ma, K. Ye, G. Wang, M. Duan, K. Cheng, G. Wang, D. Cao, Facile fabrication of gold coated nickel nanoarrays and its excellent catalytic performance towards sodium borohydride electro-oxidation, Appl. Surf. Sci. 414 (2017) 353-360.

[10] V.A. Grinberg, N.A. Mayorova, A.A. Korlyukov, A.A. Pasynskii, Direct borohydride oxidation electrocatalysts based on $\mathrm{Ni}-\mathrm{Ru} / \mathrm{C}$ and $\mathrm{Ni}-\mathrm{Ru}-\mathrm{F} / \mathrm{C}$ alloys, Russ. J. Electrochem. 46 (2010) 1289-1296.

[11] A.G. Oshchepkov, G. Braesch, S. Ould-Amara, G. Rostamikia, G. Maranzana, A. Bonnefont, V. Papaefthimiou, M.J. Janik, M. Chatenet, E.R. Savinova, Nickel Metal Nanoparticles as Anode Electrocatalysts for Highly Efficient Direct Borohydride Fuel Cells, ACS Catal. 9 (2019) 8520-8528.

[12] A.G. Oshchepkov, A. Bonnefont, E.R. Savinova, On the Influence of the Extent of Oxidation on the Kinetics of the Hydrogen Electrode Reactions on Polycrystalline Nickel, Electrocatalysis. 11 (2020) 133-142.

[13] A.G. Oshchepkov, A. Bonnefont, S.N. Pronkin, O. V. Cherstiouk, C. Ulhaq-Bouillet, V. 
Papaefthimiou, V.N. Parmon, E.R. Savinova, Nanostructured nickel nanoparticles supported on vulcan carbon as a highly active catalyst for the hydrogen oxidation reaction in alkaline media, J. Power Sources. 402 (2018) 447-452.

[14] P.Y. Olu, A. Zadick, N. Job, M. Chatenet, Anode Electrocatalysts for Direct Borohydride and Direct Ammonia Borane Fuel Cells, Electrocatal. Low Temp. Fuel Cells Fundam. Recent Trends. 4 (2017) 317-346.

[15] G. Braesch, A.G. Oshchepkov, A. Bonnefont, F. Asonkeng, T. Maurer, G. Maranzana, E.R. Savinova, M. Chatenet, Nickel 3D Structures Enhanced by Electrodeposition of Nickel Nanoparticles as High Performance Anodes for Direct Borohydride Fuel Cells, ChemElectroChem. 7 (2020) 1789-1799.

[16] G. Braesch, Z. Wang, S. Sankarasubramanian, A.G. Oshchepkov, A. Bonnefont, E.R. Savinova, V. Ramani, M. Chatenet, A high performance direct borohydride fuel cell using bipolar interfaces and noble metal-free Ni-based anodes, J. Mater. Chem. A. 8 (2020) 20543-20552.

[17] J.P.I. De Souza, S.L. Queiroz, F.C. Nart, The use of mass spectrometry in electrochemical measurements - The DEMS technique, Quim. Nova. 23 (2000) 384-391.

[18] J.P.I. De Souza, S.L. Queiroz, K. Bergamaski, E.R. Gonzalez, F.C. Nart, Electro-oxidation of ethanol on Pt, Rh, and PtRh electrodes. A study using DEMS and in-situ FTIR techniques, J. Phys. Chem. B. 106 (2002) 9825-9830.

[19] K. Bergamaski, A.L.N. Pinheiro, E. Teixeira-Neto, F.C. Nart, Nanoparticle size effects on methanol electrochemical oxidation on carbon supported platinum catalysts, J. Phys. Chem. B. 110 (2006) 19271-19279.

[20] M. Grdeń, M. Alsabet, G. Jerkiewicz, Surface science and electrochemical analysis of nickel foams, ACS Appl. Mater. Interfaces. 4 (2012) 3012-3021.

[21] G. Kresse, J. Furthmüller, Efficiency of ab-initio total energy calculations for metals and semiconductors using a plane-wave basis set, Comput. Mater. Sci. 6 (1996) 15-50.

[22] G. Kresse, J. Furthmüller, Efficient iterative schemes for ab initio total-energy calculations using a plane-wave basis set, Phys. Rev. B. 54 (1996) 11169-11186.

[23] G. Kresse, J. Hafner, Ab initio molecular dynamics for liquid metals, Phys. Rev. B. 47 (1993) 558-561.

[24] G. Kresse, D. Joubert, From ultrasoft pseudopotentials to the projector augmented-wave method, Phys. Rev. B. 59 (1999) 1758-1775.

[25] N.A.W. Holzwarth, G.E. Matthews, R.B. Dunning, A.R. Tackett, Y. Zeng, Comparison of the projector augmented-wave, pseudopotential, and linearized augmented-plane-wave formalisms for density-functional calculations of solids, Phys. Rev. B. 55 (1997) 20052017.

[26] J.P. Perdew, J.A. Chevary, S.H. Vosko, K.A. Jackson, M.R. Pederson, D.J. Singh, C. Fiolhais, Atoms, molecules, solids, and surfaces: Applications of the generalized gradient approximation for exchange and correlation, Phys. Rev. B. 46 (1992) 6671-6687. 
[27] G. Rostamikia, M.J. Janik, First principles mechanistic study of borohydride oxidation over the Pt(111) surface, Electrochim. Acta. 55 (2010) 1175-1183.

[28] A.G. Oshchepkov, A. Bonnefont, V.A. Saveleva, V. Papaefthimiou, S. Zafeiratos, S.N. Pronkin, V.N. Parmon, E.R. Savinova, Exploring the Influence of the Nickel Oxide Species on the Kinetics of Hydrogen Electrode Reactions in Alkaline Media, Top. Catal. 59 (2016) 1319-1331.

[29] P.Y. Olu, A. Bonnefont, G. Braesch, V. Martin, E.R. Savinova, M. Chatenet, Influence of the concentration of borohydride towards hydrogen production and escape for borohydride oxidation reaction on $\mathrm{Pt}$ and Au electrodes - experimental and modelling insights, J. Power Sources. 375 (2018) 300-309.

[30] S.A.S. Machado, L.A. Avaca, The hydrogen evolution reaction on nickel surfaces stabilized by H-absorption, Electrochim. Acta. 39 (1994) 1385-1391.

[31] G. Braesch, A. Bonnefont, V. Martin, E.R. Savinova, M. Chatenet, Borohydride oxidation reaction mechanisms and poisoning effects on $\mathrm{Au}, \mathrm{Pt}$ and $\mathrm{Pd}$ bulk electrodes: From model (low) to direct borohydride fuel cell operating (high) concentrations, Electrochim. Acta. 273 (2018) 483-494.

[32] P.Y. Olu, A. Bonnefont, M. Rouhet, S. Bozdech, N. Job, M. Chatenet, E. Savinova, Insights into the potential dependence of the borohydride electrooxidation reaction mechanism on platinum nanoparticles supported on ordered carbon nanomaterials, Electrochim. Acta. 179 (2015) 637-646.

[33] E.B. Ferreira, G. Jerkiewicz, On the Electrochemical Reduction of $\beta-\mathrm{Ni}(\mathrm{OH}) 2$ to Metallic Nickel, Electrocatalysis. 12 (2021) 199-209.

[34] D.S. Hall, D.J. Lockwood, C. Bock, B.R. MacDougall, Nickel hydroxides and related materials: a review of their structures, synthesis and properties, Proc. R. Soc. A Math. Phys. Eng. Sci. 471 (2014) 20140792.

[35] F.H.B. Lima, A.M. Pasqualeti, M.B. Molina Concha, M. Chatenet, E.A. Ticianelli, Borohydride electrooxidation on Au and Pt electrodes, Electrochim. Acta. 84 (2012) 202212.

[36] B.M. Concha, M. Chatenet, F. Maillard, E.A. Ticianelli, F.H.B. Lima, R.B. de Lima, In situ infrared (FTIR) study of the mechanism of the borohydride oxidation reaction, Phys. Chem. Chem. Phys. 12 (2010) 11507-11516.

[37] B.M. Concha, M. Chatenet, C. Coutanceau, F. Hahn, In situ infrared (FTIR) study of the borohydride oxidation reaction, Electrochem. Commun. 11 (2009) 223-226.

[38] D. Duan, H. Liu, X. You, H. Wei, S. Liu, Anodic behavior of carbon supported Cu@ Ag core-shell nanocatalysts in direct borohydride fuel cells, J. Power Sources. 293 (2015) 292-300.

[39] D. Duan, H. Liu, Q. Wang, Y. Wang, S. Liu, Kinetics of sodium borohydride direct oxidation on carbon supported $\mathrm{Cu}-\mathrm{Ag}$ bimetallic nanocatalysts, Electrochim. Acta. 198 (2016) 212-219. 
[40] C. Grimmer, M. Grandi, R. Zacharias, B. Cermenek, H. Weber, C. Morais, T.W. Napporn, S. Weinberger, A. Schenk, V. Hacker, The electrooxidation of borohydride: A mechanistic study on palladium (Pd/C) applying RRDE, 11B-NMR and FTIR, Appl. Catal. B Environ. 180 (2016) 614-621.

[41] D. Peak, G.W. Luther, D.L. Sparks, ATR-FTIR spectroscopic studies of boric acid adsorption on hydrous ferric oxide, Geochim. Cosmochim. Acta. 67 (2003) 2551-2560.

[42] F.Y. Zhu, C.H. Fang, Y. Fang, Y.Q. Zhou, H.W. Ge, H.Y. Liu, Structure of aqueous potassium metaborate solution, J. Mol. Struct. 1070 (2014) 80-85.

[43] D. Li, G. Zhou, S. Gu, T. Zhang, L. Meng, Y. Guo, T. Deng, Thermodynamic and Dynamic Modeling of the Boron Species in Aqueous Potassium Borate Solution, ACS Omega. 5 (2020) 15835-15842.

[44] A. Lopalco, A.A. Lopedota, V. Laquintana, N. Denora, V.J. Stella, Boric Acid, a Lewis Acid With Unique and Unusual Properties: Formulation Implications, J. Pharm. Sci. 109 (2020) 2375-2386.

[45] A. Graff, E. Barrez, P. Baranek, M. Bachet, P. Bénézeth, Complexation of Nickel Ions by Boric Acid or (Poly)borates, J. Solution Chem. 46 (2017) 25-43.

[46] A.M. Pasqualeti, P.Y. Olu, M. Chatenet, F.H.B. Lima, Borohydride electrooxidation on carbon-supported noble metal nanoparticles: Insights into hydrogen and hydroxyborane formation, ACS Catal. 5 (2015) 2778-2787.

[47] M. Belén Molina Concha, M. Chatenet, F.H.B. Lima, E.A. Ticianelli, In situ Fourier transform infrared spectroscopy and on-line differential electrochemical mass spectrometry study of the $\mathrm{NH}_{3} \mathrm{BH}_{3}$ oxidation reaction on gold electrodes, Electrochim. Acta. 89 (2013) 607-615.

[48] L.C. Nagle, J.F. Rohan, Ammonia borane oxidation at gold microelectrodes in alkaline solutions, J. Electrochem. Soc. 153 (2006) 773-776.

[49] A.G. Oshchepkov, A. Bonnefont, V.N. Parmon, E.R. Savinova, On the effect of temperature and surface oxidation on the kinetics of hydrogen electrode reactions on nickel in alkaline media, Electrochim. Acta. 269 (2018) 111-118.

[50] E. Santos, P. Hindelang, P. Quaino, E.N. Schulz, G. Soldano, W. Schmickler, Hydrogen electrocatalysis on single crystals and on nanostructured electrodes, ChemPhysChem. 12 (2011) 2274-2279.

[51] Y. Zhou, T. Yamaguchi, K. Ikeda, K. Yoshida, T. Otomo, C. Fang, W. Zhang, F. Zhu, Dihydrogen Bonds in Aqueous NaBD4 Solution by Neutron and X-ray Diffraction, J. Phys. Chem. Lett. 11 (2020) 1622-1628. 


\section{Figures}
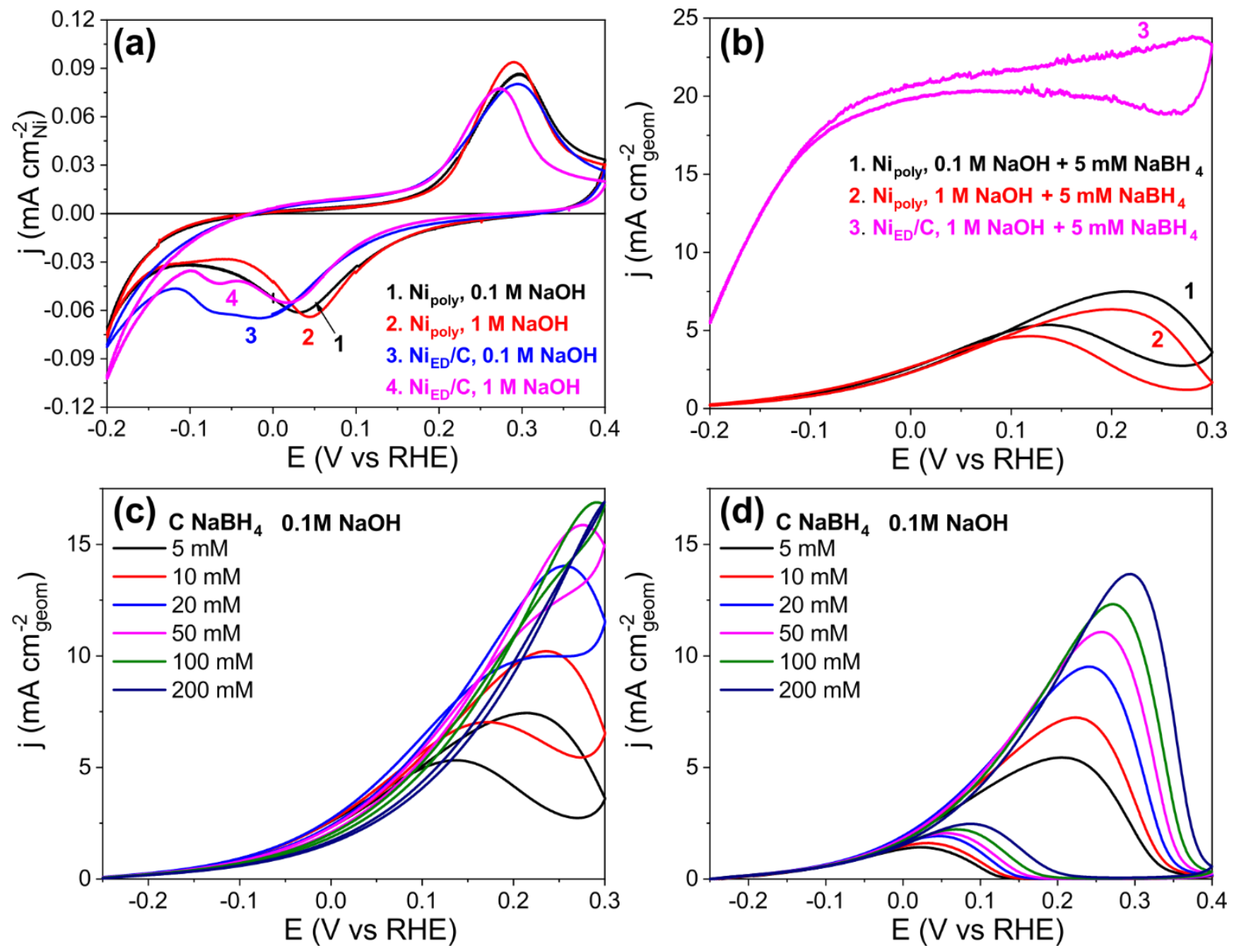

Fig. 1. $\mathrm{CV}$ curves of a polycrystalline $\mathrm{Ni}$ disk $\left(\mathrm{ECSA}=0.26 \pm 0.01 \mathrm{~cm}^{2}\right)$ or $\mathrm{Ni}_{\mathrm{ED}} / \mathrm{C}$ nanoparticles $\left(E C S A=14 \pm 1 \mathrm{~cm}^{2}\right.$ ) obtained at $v=20 \mathrm{mV} \mathrm{s}^{-1}$ in the absence (a) or in the presence of $\mathrm{NaBH}_{4}(\mathrm{~b}$ $-\mathrm{d}$ ). CVs of the BOR $\left(\mathrm{b}-\mathrm{d}\right.$ ) are recorded at $\omega=1600 \mathrm{rpm}$ with $80 \%$ (for $\mathrm{Ni} \mathrm{ED}_{\mathrm{ED}} / \mathrm{C}$ ) or $85 \%$ (for $\mathrm{Ni}_{\text {poly }}$ ) IR compensation. The data for $\mathrm{Ni}$ ED/C are replotted from Ref. [11] with permission from ACS publishing. 

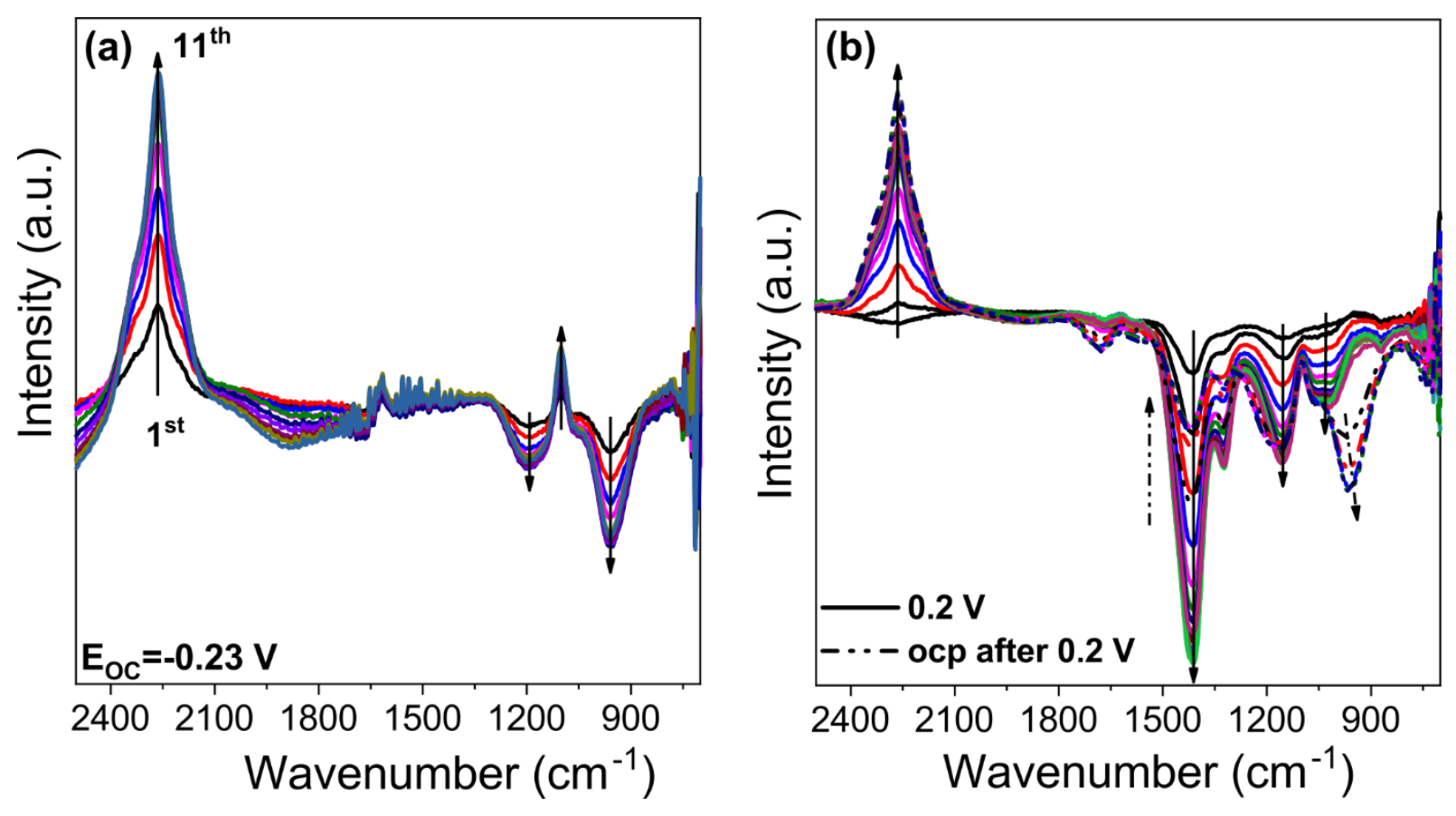

Fig. 2. In situ FTIR spectra of a polycrystalline Ni disk in $0.2 \mathrm{M} \mathrm{NaBH}_{4}+0.1 \mathrm{M} \mathrm{NaOH}$ recorded as a function of time at given potential values, (a) $E=-0.23 \mathrm{~V} v s \mathrm{RHE}$ and (b) $E=0.2 \mathrm{~V} v s$ RHE. 
(a) $0.2 \mathrm{M} \mathrm{NaBH}_{4}+0.1 \mathrm{M} \mathrm{NaOH}$ (in $\mathrm{H}_{2} \mathrm{O}$ )

(b) $0.2 \mathrm{M} \mathrm{NaBD}_{4}+0.1 \mathrm{M} \mathrm{NaOD}$ (in $\mathrm{D}_{2} \mathrm{O}$ )
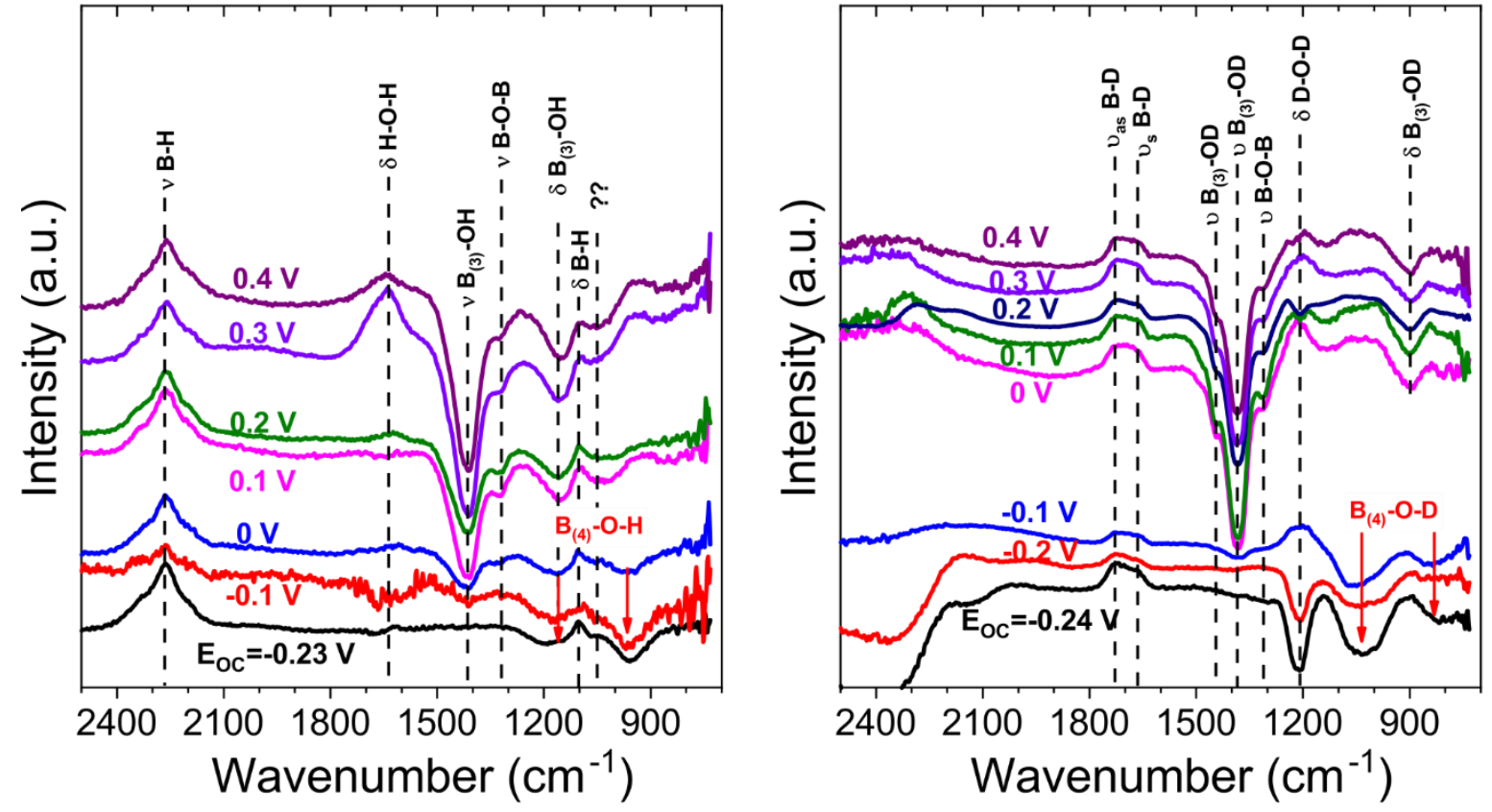

(c) $0.2 \mathrm{M} \mathrm{NaBD}_{4}+0.1 \mathrm{M} \mathrm{NaOH}$ (in $\mathrm{H}_{2} \mathrm{O}$ )

(d) $0.2 \mathrm{M} \mathrm{NH}_{3} \mathrm{BH}_{3}+0.1 \mathrm{M} \mathrm{NaOH}\left(\right.$ in $\mathrm{H}_{2} \mathrm{O}$ )
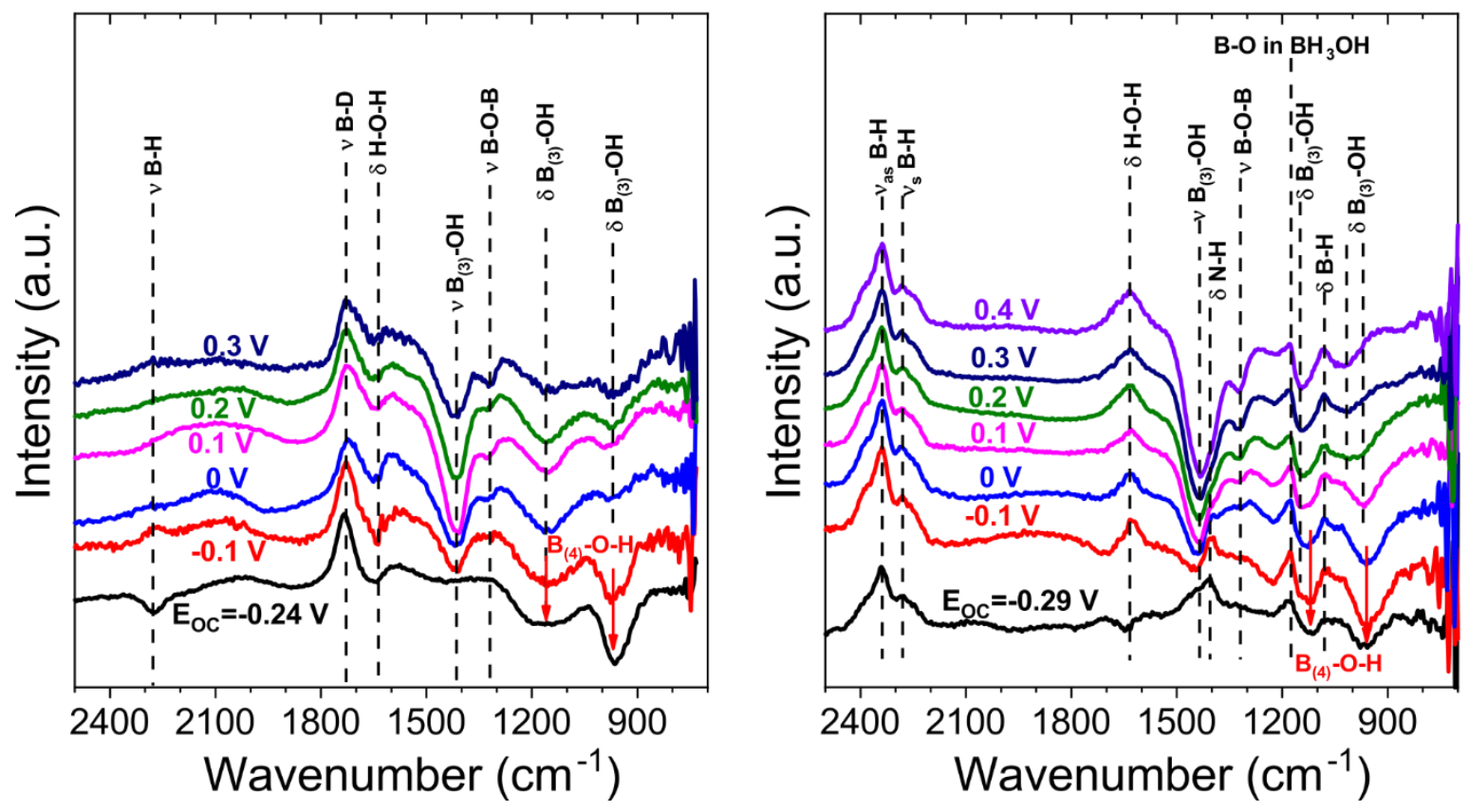

Fig. 3. In situ FTIR spectra of a polycrystalline Ni disk in (a) $0.2 \mathrm{M} \mathrm{NaBH}_{4}+0.1 \mathrm{M} \mathrm{NaOH}$ in $\mathrm{H}_{2} \mathrm{O}$, (b) $0.2 \mathrm{M} \mathrm{NaBD}_{4}+0.1 \mathrm{M} \mathrm{NaOD}$ in $\mathrm{D}_{2} \mathrm{O}$, (c) $0.2 \mathrm{M} \mathrm{NaBD}_{4}+0.1 \mathrm{M} \mathrm{NaOH}$ in $\mathrm{H}_{2} \mathrm{O}$, (d) 0.2 $\mathrm{M} \mathrm{BH}_{3} \mathrm{NH}_{3}+0.1 \mathrm{M} \mathrm{NaOH}$ at different electrode potentials as specified in the plots. 

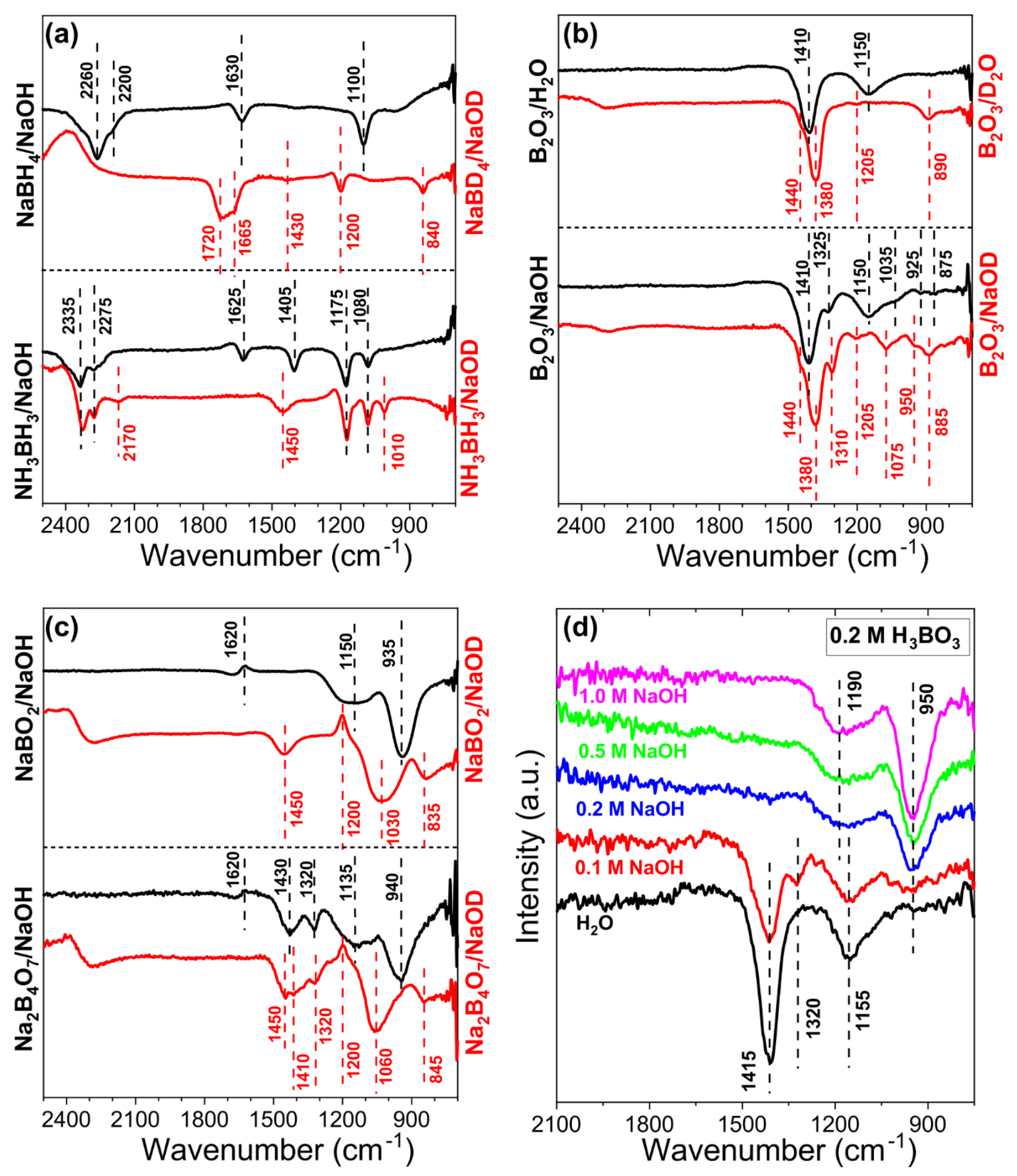

Fig. 4. Infrared spectra recorded in ATR configuration for different reference solutions: $2 \mathrm{M}$ $\mathrm{NaBH}_{4}, 2 \mathrm{M} \mathrm{NaBD}_{4}, 2 \mathrm{M} \mathrm{NH}_{3} \mathrm{BH}_{3}, 2 \mathrm{M} \mathrm{NaBO}, 0.2 \mathrm{M} \mathrm{H}_{3} \mathrm{BO}_{3}$, sat. $\mathrm{B}_{2} \mathrm{O}_{3}$ and saturated $\mathrm{Na}_{2} \mathrm{~B}_{4} \mathrm{O}_{7}$ in either $0.1 \mathrm{M} \mathrm{NaOH} / \mathrm{NaOD}$ or pure $\mathrm{H}_{2} \mathrm{O} / \mathrm{D}_{2} \mathrm{O}$. 

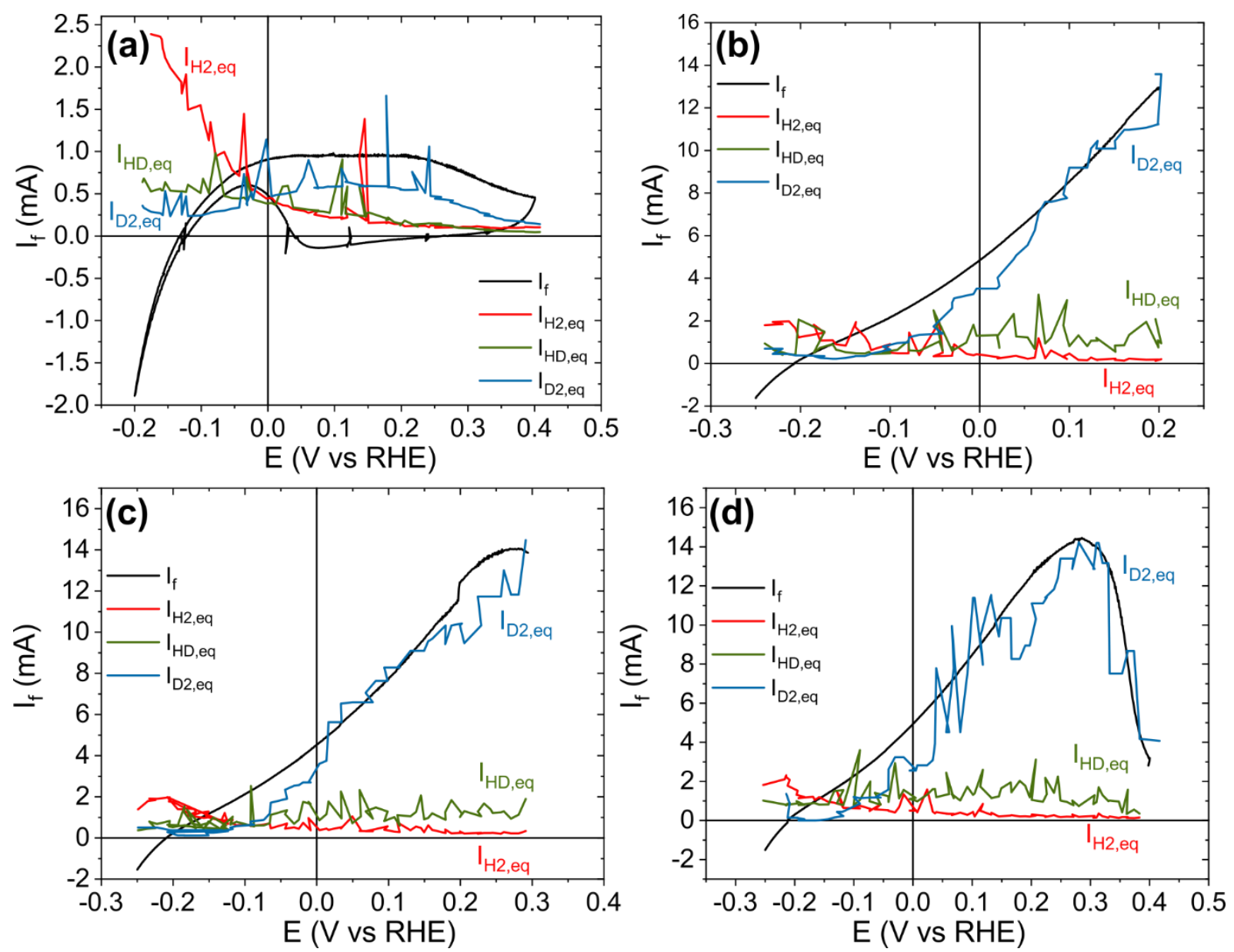

Fig. 5. DEMS measurement of an etched $\mathrm{Ni}_{\text {felt }}$ in Ar-saturated $1 \mathrm{M} \mathrm{NaOH}+$ (a) $5 \mathrm{mM}$ or (b, c, d) $50 \mathrm{mM} \mathrm{NaBD}_{4}, v=10 \mathrm{mV} \mathrm{s}^{-1}$. The ionic $\left(\mathrm{H}_{2}, \mathrm{HD}, \mathrm{D}_{2}\right)$ currents are recalculated into the faradic ones using the calibration constant determined independently $\left(K=2.19710^{10}\right)$. Ionic currents acquired in $50 \mathrm{mM} \mathrm{NaBD} 4$ were smoothed after the measurements using a $50 \%$ percentile filter method with a 10-points window. 

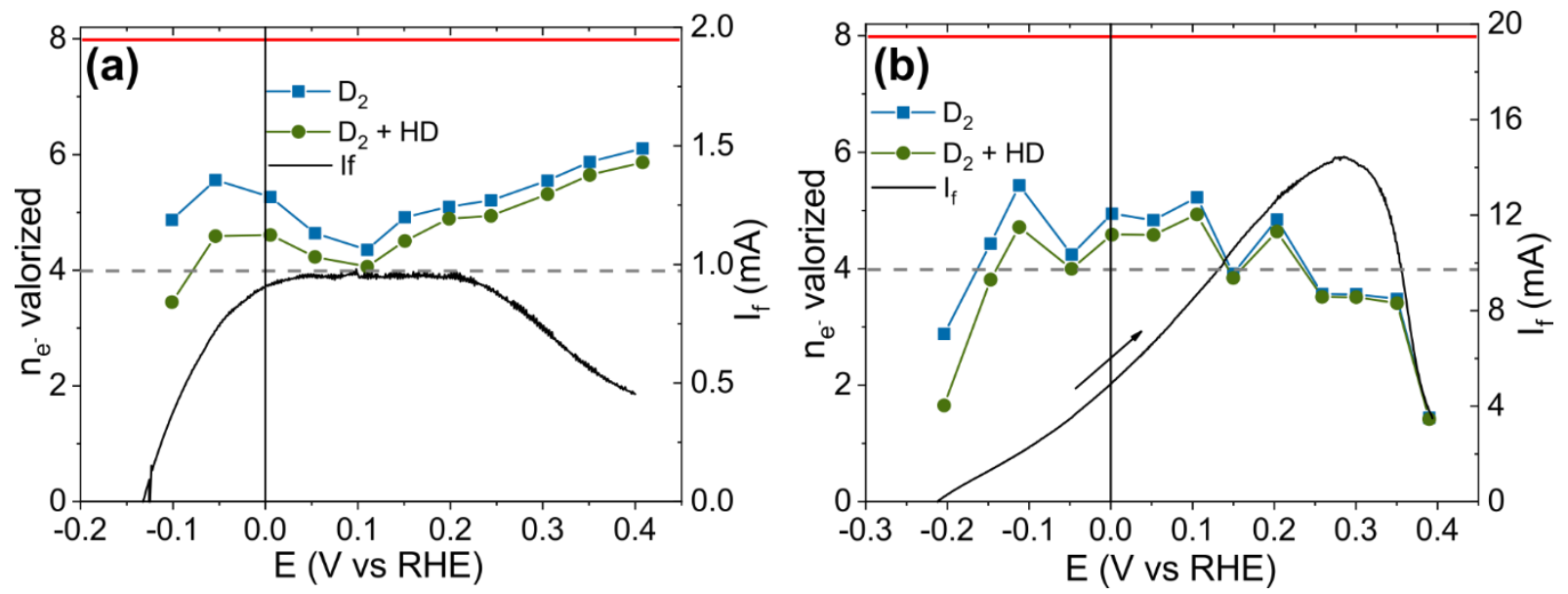

Fig. 6. Estimation of the number of electrons produced during the BOR on $\mathrm{Ni}$ in the anodic sweep in Ar-saturated $1 \mathrm{M} \mathrm{NaOH}+$ (a) $5 \mathrm{mM}$ and (b) $50 \mathrm{mM} \mathrm{NaBD}_{4}$. Calculation made with either the $\mathrm{HD}$ and $\mathrm{D}_{2}$ or $\mathrm{D}_{2}$ only contribution using Eq4. Red line denotes maximum number of electrons $\left(8 \mathrm{e}^{-}\right)$which could be transferred during the BOR. 

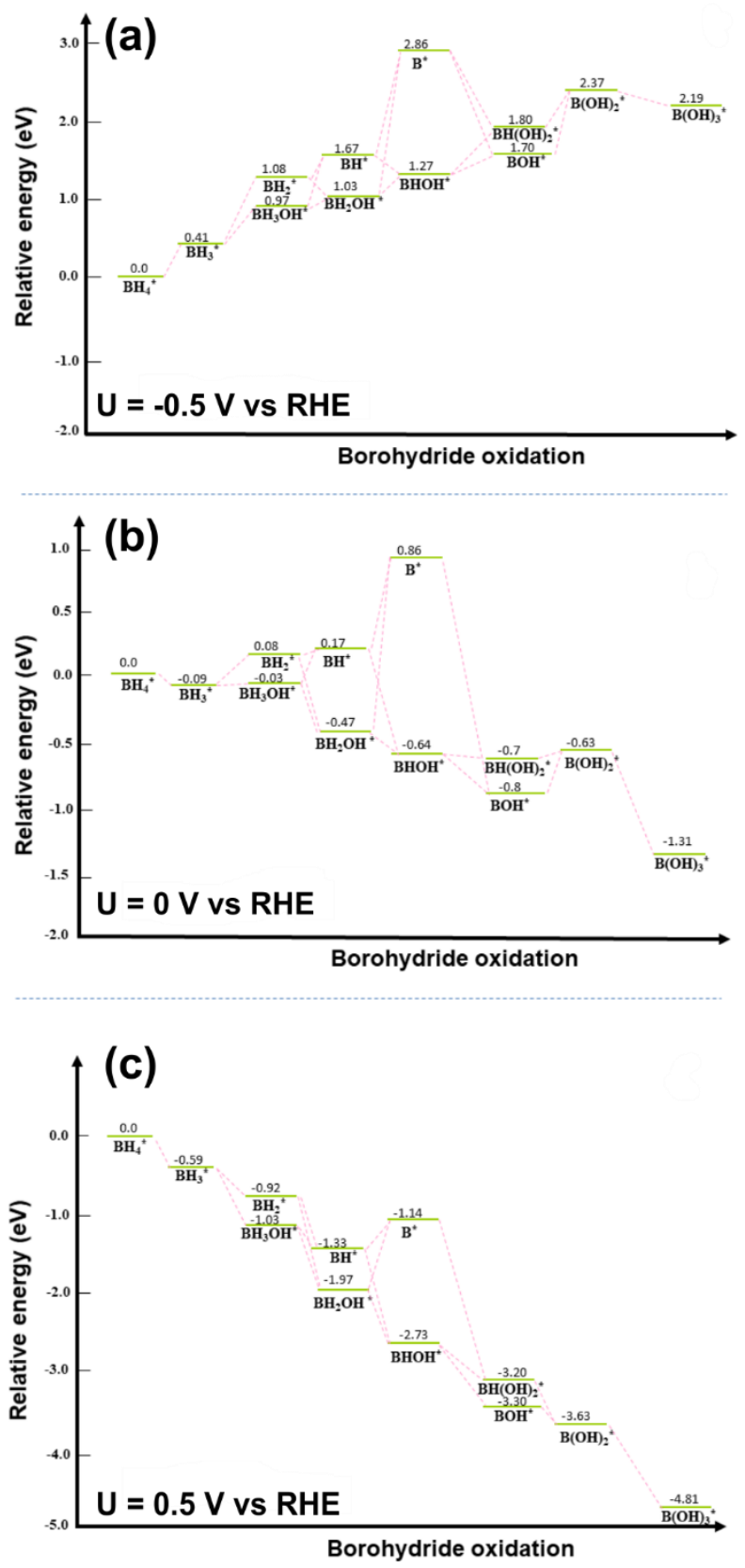

Fig 7. Borohydride oxidation reaction energy diagrams for the Ni(111) surface at a) $E=-0.5 \mathrm{~V}$ vs RHE, b) $E=0 \mathrm{~V} v s$ RHE, and c) $E=0.5 \mathrm{~V} v s$ RHE. 

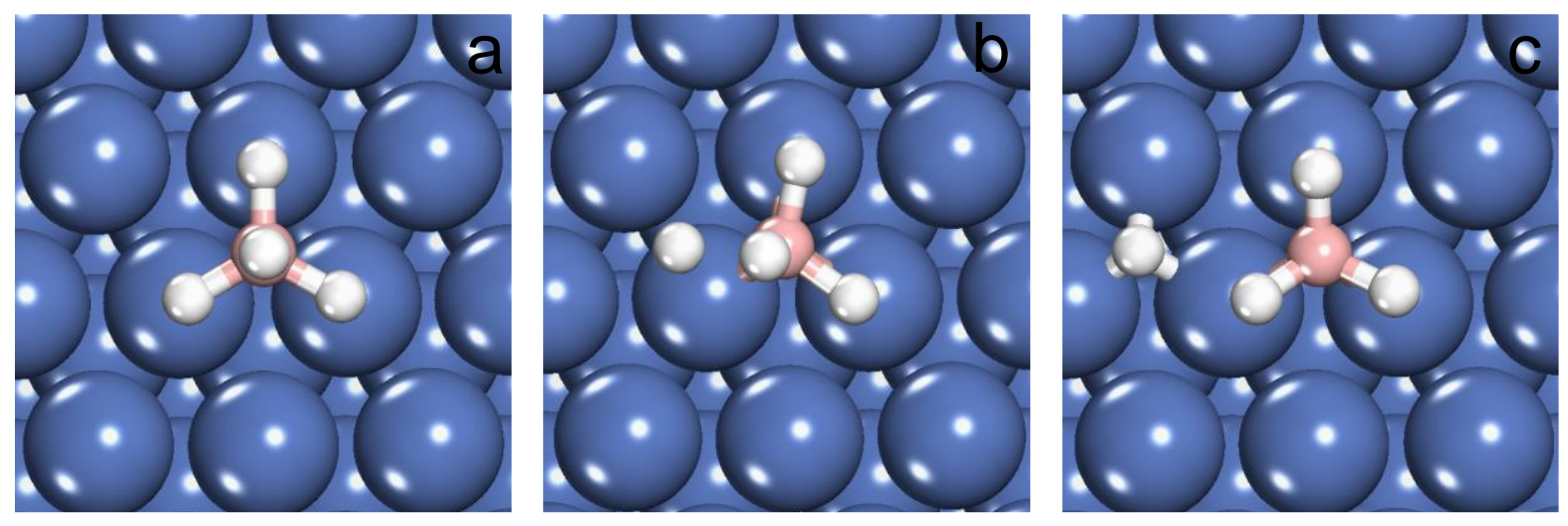

Fig. 8. DFT optimized a) initial, b) transition, and c) final states for dissociation of $\mathrm{BH}_{4} *$ to $\mathrm{BH}_{3} *$ and $\mathrm{H}^{*}$ on the $\mathrm{Ni}(111)$ surface. 

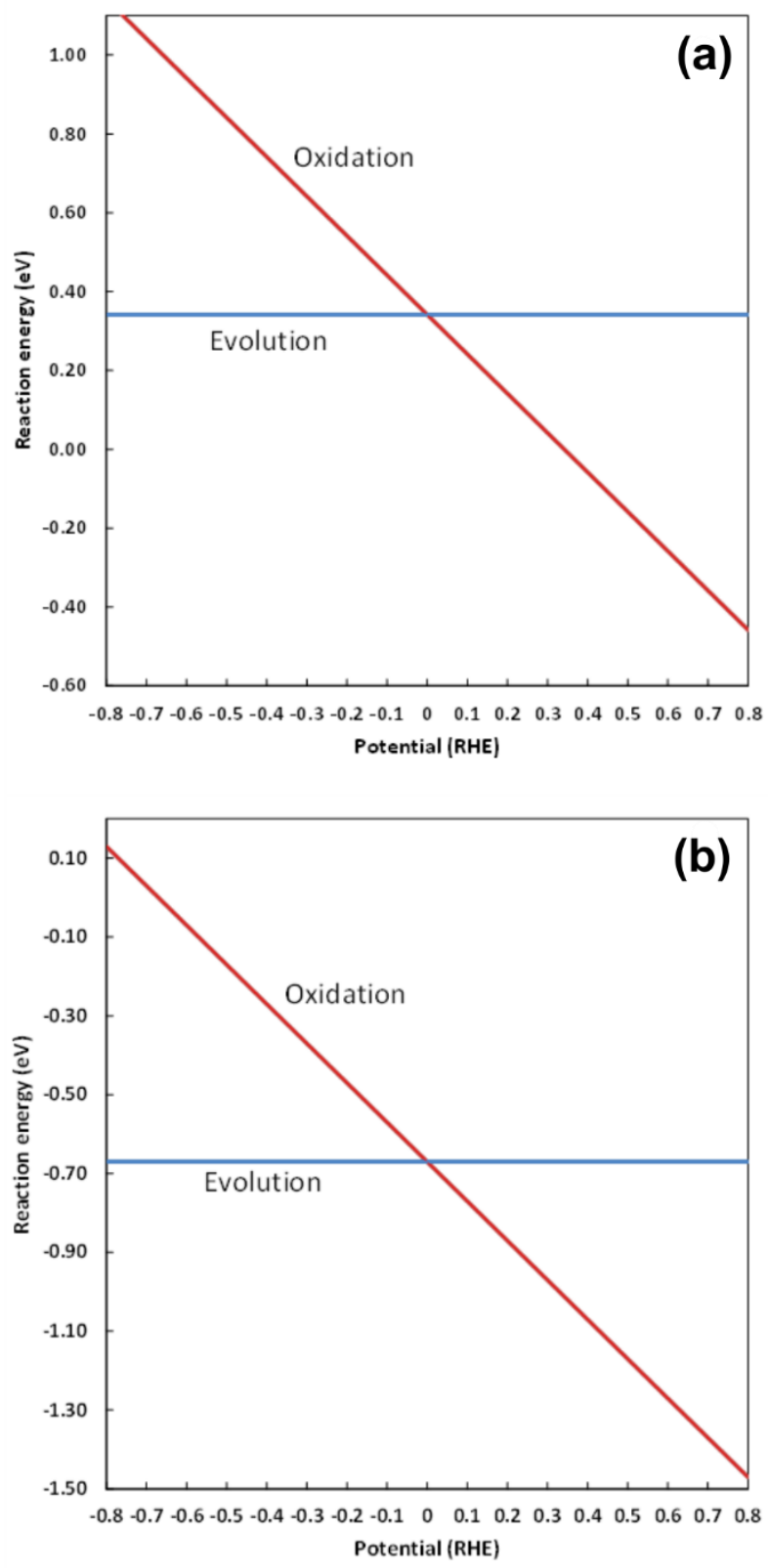

Fig. 9. Reaction energies for the oxidation of $\mathrm{H}^{*}\left(\mathrm{H}^{*} \rightarrow \mathrm{H}^{+}+\mathrm{e}^{-}+^{*}\right)$ and for hydrogen evolution $\left(\mathrm{H}^{*} \rightarrow \mathrm{H}_{2}+*\right)$ from the $\mathrm{Ni}(111)$ surface are plotted as a function of potential for a) conversion of $1 / 9 \mathrm{ML}$ of $\mathrm{H}^{*}$ to $0 \mathrm{ML}$ and $\mathrm{b}$ ) conversion of $10 / 9 \mathrm{ML}$ of $\mathrm{H}^{*}$ to $1 \mathrm{ML}$. 


\section{Tables}

Table 1. Band frequencies recorded for the references solutions in the ATR-FTIR measurements

\begin{tabular}{|c|c|c|c|c|c|c|}
\hline \multirow{3}{*}{$\begin{array}{l}\text { Type of } \\
\text { vibrations }\end{array}$} & \multicolumn{2}{|l|}{ B-H compounds } & \multicolumn{4}{|c|}{ B-O $(\mathrm{H})$ compounds } \\
\hline & $\mathrm{NaBH}_{4}+\mathrm{NaOH}$ & $\begin{array}{l}\mathrm{NH}_{3} \mathrm{BH}_{3}+ \\
\mathrm{NaOH}\end{array}$ & $\mathrm{B}_{2} \mathrm{O}_{3}+\mathrm{H}_{2} \mathrm{O}$ & $\mathrm{B}_{2} \mathrm{O}_{3}+\mathrm{NaOH}$ & $\mathrm{NaBO}_{2}+\mathrm{NaOH}$ & $\begin{array}{l}\mathrm{Na}_{2} \mathrm{~B}_{4} \mathrm{O}_{7} \\
+\mathrm{NaOH}\end{array}$ \\
\hline & $\mathrm{NaBD}_{4}+\mathrm{NaOD}$ & $\begin{array}{l}\mathrm{NH}_{3} \mathrm{BH}_{3}+ \\
\mathrm{NaOD}\end{array}$ & $\mathrm{B}_{2} \mathrm{O}_{3}+\mathrm{D}_{2} \mathrm{O}$ & $\mathrm{B}_{2} \mathrm{O}_{3}+\mathrm{NaOD}$ & $\mathrm{NaBO}_{2}+\mathrm{NaOD}$ & $\begin{array}{l}\mathrm{Na}_{2} \mathrm{~B}_{4} \mathrm{O}_{7} \\
+\mathrm{NaOD}\end{array}$ \\
\hline$v(\mathrm{~B}-\mathrm{H})$ & 2260,2200 & 2335,2275 & & & & \\
\hline$v$ (B-D) & 1720,1665 & & & & & \\
\hline$\delta(\mathbf{B}-\mathbf{H})$ & 1100 & 1080 & & & & \\
\hline$\delta(\mathrm{B}-\mathrm{D})$ & 840 & & & & & \\
\hline$\delta(\mathbf{H}-\mathrm{O}-\mathrm{H})$ & 1630 & 1625 & & & 1620 & 1620 \\
\hline$\delta(H-O-D)$ & 1430 & & & & 1450 & 1450 \\
\hline$\delta(\mathrm{D}-\mathrm{O}-\mathrm{D})$ & 1200 & 1200 & 1205 & 1205 & 1200 & 1200 \\
\hline$v\left(B_{(3)}-\mathrm{OH}\right)$ & & & 1410 & 1410 & & 1430 \\
\hline$v\left(\mathbf{B}_{(3)}-\mathrm{OD}\right)$ & & & 1440,1380 & 1440,1380 & & 1410 \\
\hline$\delta\left(\mathbf{B}_{(3)}-\mathrm{O}-\mathrm{H}\right)$ & & & 1150 (broad) & $\sim 1150$ (broad) & & \\
\hline$\delta\left(\mathbf{B}_{(3)}-\mathrm{O}-\mathrm{D}\right)$ & & & 890 & 885 & & \\
\hline $\begin{array}{l}v / \delta\left(\mathbf{B}_{(4)}-\mathrm{O}-\mathrm{H}\right) \text { in } \\
\mathrm{B}(\mathrm{OH}) 4-\end{array}$ & & & & $\sim 1150$ (broad) & $\sim 1150$ (broad) & $\begin{array}{l}1135 \\
\text { (broad) }\end{array}$ \\
\hline $\begin{array}{l}v / \delta\left(\mathbf{B}_{(4)}-\mathrm{O}-\mathrm{D}\right) \text { in } \\
\mathbf{B}(\mathbf{O D})_{4}^{-}\end{array}$ & & & & 1075 & $\sim 1030$ (broad) & 1060 \\
\hline $\mathbf{v} / \boldsymbol{\delta}\left(\mathbf{B}_{(4)}-\mathrm{O}-\mathrm{H}\right)$ & & & & 925 & 935 & 940 \\
\hline$v / \delta\left(B_{(4)}-O-D\right)$ & & & & $\sim 850$ & 835 & 845 \\
\hline & & & & & & \\
\hline$v(B-O-B)$ & & & & 1325 & & 1320 \\
\hline$v(B-O-B)$ & & & & 1310 & & 1320 \\
\hline$v(\mathrm{~N}-\mathrm{H})$ & & & & & & \\
\hline$v(\mathrm{~N}-\mathrm{D})$ & & 2170 & & & & \\
\hline$\delta(\mathrm{H}-\mathrm{N}-\mathrm{H})$ & & 1405 & & & & \\
\hline$\delta(\mathrm{D}-\mathrm{N}-\mathrm{D})$ & & 1010 & & & & \\
\hline $\begin{array}{l}\mathbf{v}(\mathbf{B}-\mathbf{O}) \text { in } \\
\text { polyborates? }\end{array}$ & & & & $\begin{array}{l}1035,925 \\
875 \\
950\end{array}$ & & \\
\hline $\begin{array}{l}\text { B-O in } \\
\mathrm{BH}_{3} \mathrm{OH}^{-}\end{array}$ & & $1175 / 1175$ & & & & \\
\hline
\end{tabular}


Table 2. Desorption energies of stable intermediates compare to the surface oxidation elementary reaction energy for the same surface species.

\begin{tabular}{|c|c|c|c|}
\hline $\begin{array}{c}\text { Surface } \\
\text { Intermediates }\end{array}$ & $\begin{array}{c}\text { Desorption energy } \\
(\mathrm{eV})\end{array}$ & $\begin{array}{c}\text { Next Oxidation } \\
\text { Product }\end{array}$ & $\begin{array}{c}\text { Oxidation reaction } \\
\text { energy at 0 V-RHE }(\mathrm{eV})\end{array}$ \\
\hline $\mathrm{BH}_{3}{ }^{*}$ & 2.19 & $\mathrm{BH}_{2}{ }^{*}$ & 0.17 \\
\hline $\mathrm{BH}_{2} \mathrm{OH}^{*}$ & 1.27 & $\mathrm{BHOH}^{*}$ & -0.17 \\
\hline $\mathrm{BH}(\mathrm{OH})_{2}{ }^{*}$ & 0.49 & $\mathrm{~B}(\mathrm{OH})_{2}{ }^{*}$ & 0.07 \\
\hline
\end{tabular}

